\title{
Sustainable Development: Is This Paradigm The Remedy of All Challenges? Does Its Goals Capture The Essence of Real Development and Sustainability? With Reference to Discourses, Creativeness, Boundaries and Institutional Architecture
}

\author{
https://doi.org/10.21272/sec.3(4).97-128.2019
}

\section{Medani P. Bhandari, ORCID: https://orcid.org/0000-0003-2213-2349}

$\mathrm{PhD}$, Professor, Department of Natural Resource \& Environment / Sustainability Studies, Akamai University, USA; Professor, Department of Finance and Entrepreneurship, Sumy State University, Ukraine

"The Sustainable Development Goals (SDGs) are the blueprint to achieve a better and more sustainable future for all. They address the global challenges we face, including those related to poverty, inequality, climate, environmental degradation, prosperity, and peace and justice. The Goals interconnect and in order to leave no one behind, it is important that we achieve each Goal and target by 2030" (United Nation 2015). "The Sustainable Development Goals (SDGs), otherwise known as the Global Goals, are a universal call to action to end poverty, protect the planet and ensure that all people enjoy peace and prosperity" (UNDP, 2019).

\begin{abstract}
This paper summarizes the arguments and counterarguments within the scientific discussion on the issue of sustainable development with reference to discourses, creativeness, boundaries and institutional architecture. The main purpose of the research is to understand current global challenges - environmental, geographic, socioeconomic - poverty, hunger, health and inequality. Sustainability is a complex issue which interchangeably in use with sustainable development. The term sustainability discourse stands to maintain the equilibrium between nature and society and fulfill the societal demands (which could be environmental, economic and social. The boundaries of sustainable development can also be seen and evaluated in terms of institutionalization process and organizational process. More importantly, United Nation has been vigorously working to overcome with these challenges through various initiatives. In this regard, United Nation has been pioneering to minimize global challenges throughout its history. United Nation declared four decades (1960-1990) as development decade with the objective of total development primarily in the developing world. In 1990, UN presented Human Development Report 1990, and in 2000 UN declared millennium development goals (2000-2015). However, Goals were only partially achieved. With this experience, UN declared "Transforming our world: the 2030 Agenda for Sustainable Development, which declared 17 Sustainable Development Goals and 169 targets. The investigation of the topic in the paper is carried out in the following logical sequence: 1) what is the epistemological stand of sustainable development; 2) how discourses are developed, what is the limitation; 3 ) boundaries, how creativeness is incorporated in the sustainability domain and are SDGs are achievable; 4) are governments are ready to cope with the domestic and international challenges. The results of the research can be useful for many scholars, international organizations, governments, civil societies.
\end{abstract}

Keywords: United Nations, Human Development, Millennium Development Goals, Discourses, Boundaries, Creativeness, Institution, Sustainable Development, India, Nepal, Bangladesh, Pakistan, South Asia, Environmental Problems, Over Population, Poverty, Hunger, UNESCO, WHO, Epistemology.

JEL Classification: O11, O40, O53, I31.

Cite as: Medani P. Bhandari (2019). Sustainable Development: Is This Paradigm The Remedy of All Challenges? Does Its Goals Capture The Essence of Real Development and Sustainability? With Reference to Discourses, Creativeness, Boundaries and Institutional Architecture. SocioEconomic Challenges, 3(4), 97128. https://doi.org/10.21272/sec.3(4).97-128.2019.

(C) The Author, 2019. This article is published with open access at Sumy State University. 


\section{Introduction}

SDGs are achievable. To achieve SDGs goals and meet the targets, there is a need of real commitments - in so far - commitments are limited on the paper - or in the political slogans. United Nations and its member nations are taking SDGs as remedy of all problems. For example, the UN declaration 2015 states that "The Sustainable Development Goals are the blueprint to achieve a better and more sustainable future for all. They address the global challenges we face, including those related to poverty, inequality, climate, environmental degradation, prosperity, and peace and justice. The Goals interconnect and in order to leave no one behind, it is important that we achieve each Goal and target by 2030" (United Nation 2015). This statement is enough to show the hope; however, the entire declaration openly and equally treats haves and haves not country as UN stands for. However, none of the documents disclose why inequality gaps (in every span-social-economicenvironment) are widening throughout the history - rapidly increasing in recent decades? Who are responsible, and why it is increasing despite of numerous efforts from related stakeholders? Are individual countries capable enough to implement the SDGs? What is the cost of poverty, inequality, climate, environmental degradation? And where are the resources? Are global international development agencies willing to support developing nations without (agency's income-return) any stirring. Will development agencies support to developing nations without interventions in their national strategies? In so far, we have not seen any agencies support without conditions. These conditional supports primarily create super strata as supporter and recipient are automatically remain in lower strata. There is no free wheel as well as free will to developing countries who must rely on others merci to tackle the accelerating environmental problem for which they were and are not responsible for. I would say SDGs have created a temporary emotion of hope, however, mostly countries of global south may or may not be able to bring desired outcome. The current trend so far in the developed world (G20) shows questionable results. As Bertelsmann Stiftung and Sustainable Development Solutions Network 2018, indicates that the lack of economic resources, appropriate institutional arrangements; suitable monitoring evaluation tools and shortage of appropriate professional manpower are the major challenges toward the achieving SDGs. Bertelsmann Stiftung and Sustainable Development Solutions Network 2018, report summarizes that:

$>$ Most G20 countries have started SDGs implementation, but important gaps remain.

$>$ No country is on track towards achieving all SDGs.

$>$ Conflicts are leading to reversals in SDG progress.

$>$ Progress towards sustainable consumption and production patterns is too slow.

$>$ High-income countries generate negative SDG spillover effects.

$>$ Inequalities in economic and social outcomes require better data (page IX).

If so, what is the condition of developing countries? Unknown. Will remain unknown because they are still, in planning phase or for the report purpose - they might have some framework, however implementation? Is matter of big question mark (?). "To achieve the SDGs, countries must undertake major transformations of education, health, energy systems, land-use, urban development, and many other dimensions. Each transformation requires long term changes involving large numbers of stakeholders from government, business, and civil society. Since such complex transformations cannot be implemented by markets alone, governments must take the lead in mobilizing stakeholders, planning for the transformations, designing supporting policy processes, and mobilizing the public funding" (Bertelsmann Stiftung and Sustainable Development Solutions Network 2018:1). Similarly, Egron-Polak (2019) rightly shows the future directions to achieve the SDGs "SDGs address all nations - North, South, East and West; The 17 SDGs are all interconnected and show that solutions are interdependent; need holistic (multi-disciplinary) approaches; No SDG can be achieved without involvement - through research, education, and outreach - of higher education institutions; None can be achieved without international collaboration and commitment; Current trajectories of development (including in HE) are unsustainable - economically, socially, and politically; International education and research can serve to raise awareness, be at forefront of search for alternatives, demonstrate centrality of both knowledge and collaboration, gain new impetus by building on other broad agendas'. SDGs are global agendas and unified international efforts are needed to achieve them practically. Institutionalization is process (Scott 2001), must cross several prerequisites; similarly, internationalization also need combined efforts at multinational level. Therefore, it is hard judge and too early to predict. Based on past experiences, (United Nations development decades - 1960-90; agenda 21; millennium development goals) there is rational ground state that SDGs, may be partially achieved by 2030. Even to achieve partial indeed, there is a need of 
strong commitments of governments, reginal and global collaborations and strong institutional architecture for monitoring and evaluation.

\section{These questions:}

1. How theoretically and practically is sustainability discourse developed?

2. What are the boundaries and what is the linkage with creativeness?

3. Does sustainability notion help to foster creativeness and innovation?

4. What is the institutional architecture to attain the SDGs?

\section{How Theoretically and Practically Sustainability Discourse Developed?}

A "theory" is not a collection of assertions about the behavior of the actual economy but rather an explicit set of instructions for building a parallel or analogue system--a mechanical, imitation economy. A "good" model, from this point of view, will not be exactly more "real" than a poor one, but will provide better imitations. Of course, what one means by a "better imitation" will depend on the questions to which one wishes answers (Lucas 1980: 697).

Discourse is what we understand and share the meaning of idea, concept, opinion (written or unwritten). "The routine day-to-day usage of the term discourse simply refers to a stretch of text or spoken utterances that cohere into a meaningful exposition" (Chris Barker, 2004: 54).

Sustainability as such is a complex term, sustain - survive, maintain, bearing or holding capacity and ability to be able of. However, in definitional statement, mostly scholarly world cites from Our Common Future report (1987) which states "development that meets the needs of the present without compromising the ability of future generations to meet their own need" (Our Common Future, 1987). In definitional term, Sustainability and sustainable development are used interchangeably, which builds on three major areas, Environmental Sustainability, Economic Sustainability and Social Sustainability.

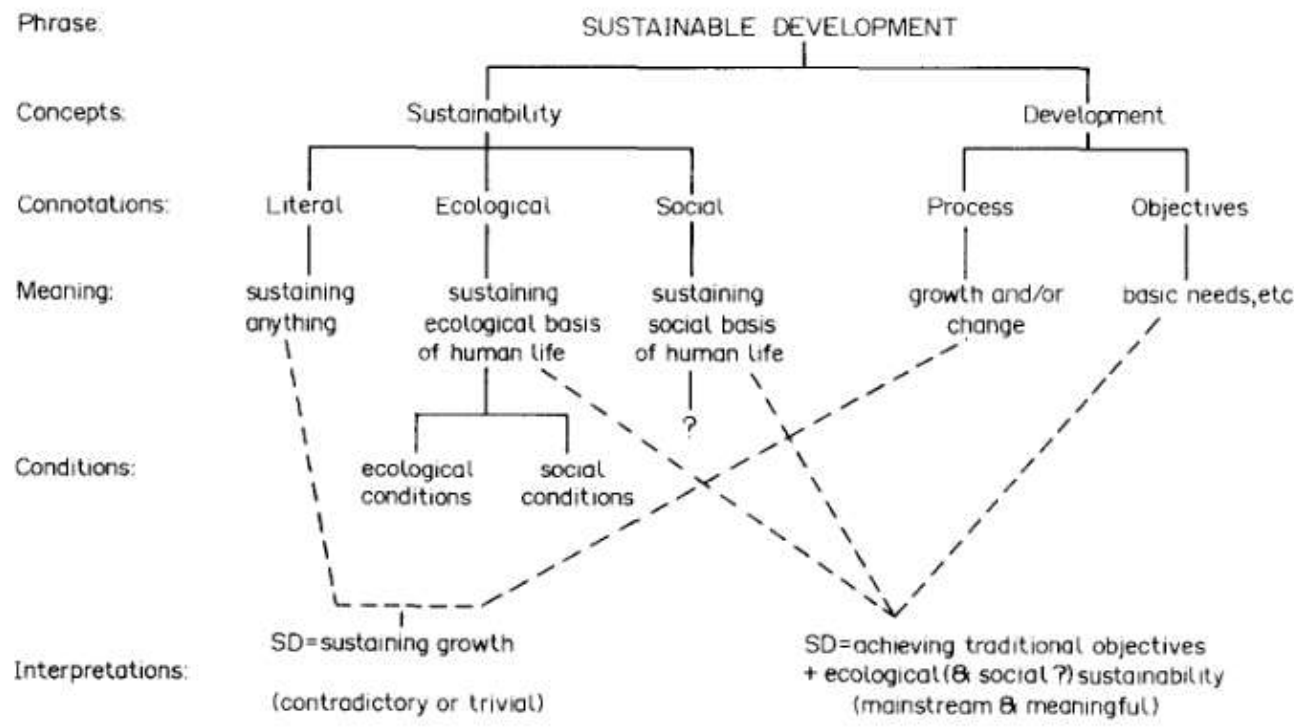

Figure 1. The semantics of sustainable development

Source: adopted from Lele, 1991: 608.

"The current state of scientific knowledge (particularly insights obtained in the last few decades) about natural and social phenomena and their interactions leads inexorably to the conclusion that anyone driven by either long-term self-interest, or concern for poverty, or concern for intergenerational equity should be willing to support the operational objectives of SD" (Lele, 1991: 612).

Lele (1991) nicely presents the complexity of sustainable development (SD) from concepts to the implementing phase, which reveals the fact that SD depends on many aspects and can be implement with 
the application of multidimensional approaches. The following table gives general scenario of SD coverage (self-explanatory).

Sustainability is a complex issue which interchangeably in use with sustainable development. Various authors have used the term various ways and defined various categories to illustrate the issue they are addressing (health, development, policy, environment, climate change, weather variation, ......) (CorralVerdugo et el., 2009; Betsy, 2010; SDSN, 2014; Boucher, 2015; United Nations, 2015; WHO, 2015; Mitchell and Walinga 2017; Tahvilzadeh, StigMontin and Cullberg, 2017; Bhandari, 2018). The term sustainability discourse stands to maintain the equilibrium between nature and society and fulfill the societal demands (which could be environmental, economic and social). Sustainability scholarship is to search the know how of how development can be maintained without hampering the natural ecosystem and how the global major problems i.e. Environmental problems, socioeconomic problems - poverty, hunger, health can be solved or at least minimize. Sustainability discourse is the overall scenario of how the concept began and how all concern stakeholders use, develop, adjust with it. Discourse can be seen as "social interaction, discourse as power and domination, discourse as communication, discourse as contextually situated, discourse as social semiosis, discourse as natural language use, discourse as complex, layered construct, sequences and hierarchies in discourse, abstract structures versus dynamic strategies in discourse, and types or genres of discourse" (Van Dijk, 2011). As Barker (2004: 54) notes "discourse is said to 'unite' language and practice and refers to regulated ways of speaking about a subject through which objects and practices acquire meaning". Sustainability discourse captures the notion of how the theories and practices have been developed and how the concern stakeholders utilized in established scenario. Sustainability discourses can be seen as creation of sustainability regime creation, by which various rules, regulations, norms, values and policy has been created. Sustainability discourses are accepted notion in the contemporary political, social, economic and environmental policy domain. As such sustainability discourse can be seen from IUCN, UNEP, WWF document "World Conservation Strategy: Living Resource Conservation for Sustainable Development” in 1980.

Table 1. Sustainability discourse

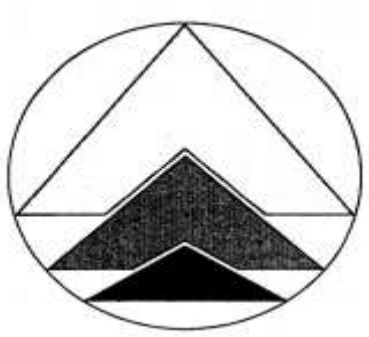

The Symbol

The circle symbolizes the biosphere - the thin covering of the planet that contains and sustains life.

The three interlocking, overlapping arrows

symbolize the three objectives of conservation: maintanance of essential ecological processes and life-support systems;

preservation of genetic diversity;

sustainable ulilization od species and ecosystems.
The World Conservation Strategy is intended to stimulate a more focused approach to the management of living resources and to provide policy guidance on how this can be carried out by three main groups:

- government policy makers and their advisers;

- conservationists and others directly concerned with living resources;

- development practitioners, including development agencies, industry and commerce, and trade unions.

1. The aim of the World Conservation Strategy is to achieve the three main objectives of living resource conservation:

a. to maintain essential ecological processes and life-support systems

b. to preserve genetic diversity

c. to ensure the sustainable utilization of species and ecosystems.................. and.........

6. The World Conservation Strategy ends by summarizing the main requirements for sustainable development, indicating conservation priorities for the Third Development Decade (section 20).

Source: IUCN-UNEP-WWF (1980-vi-vii) https://portals.iucn.org/library/sites/library/files/documents/WCS-004.pdf.

The world conservation strategy the symbol and the text clearly emphasize the importance to sustainability, which also paved the foundation of sustainability discourses. However, one can trace the originality of discourses when people began to think about the limitation of natural resources and interrelated harmonies relationships between human and nature. In this respect, we can see the modern environment conservation history and the efforts to conserve them particularly in terms of environmental problems-climate change. Sustainability discourse developed as a problem-solving tool. The meaning of sustainability has been modified as its application became popular. The following table adopted from Klarin (2018: 77), provides chronological overview of the meaning of sustainable development. 
Table 2. The chronological overview of the meaning of sustainable development in the period 1980-2018

\begin{tabular}{|c|c|}
\hline $\begin{array}{l}\text { Authors/publication and } \\
\text { year }\end{array}$ & Meaning and understanding of sustainable development \\
\hline IUCN 1980 & World Conservation Strategy \\
\hline WCED, 1987 & $\begin{array}{l}\text { Sustainable development is a development that meets the needs of the present without compromising the ability of } \\
\text { future generations to meet their own needs. }\end{array}$ \\
\hline Pearce et al., 1989 & $\begin{array}{l}\text { Sustainable development implies a conceptual socio-economic system which ensures the sustainability of goals in } \\
\text { the form of real income achievement and improvement of educational standards, health care and the overall quality } \\
\text { of life. }\end{array}$ \\
\hline Harwood, 1990 & $\begin{array}{l}\text { Sustainable development is unlimited developing system, where development is focused on achieving greater } \\
\text { benefits for humans and more efficient resource use in balance with the environment required for all humans and } \\
\text { all other species. }\end{array}$ \\
\hline $\begin{array}{l}\text { IUCN, UNDP \& WWF, } \\
1991\end{array}$ & $\begin{array}{l}\text { Sustainable development is a process of improving the quality of human life within the framework of carrying } \\
\text { capacity of the sustainable ecosystems. }\end{array}$ \\
\hline Lele, 1991 & Sustainable development is a process of targeted changes that can be repeated forever. \\
\hline Meadows, 1998 & $\begin{array}{l}\text { Sustainable development is a social construction derived from the long-term evolution of a highly complex system } \\
\text { - human population and economic development integrated into ecosystems and biochemical processes of the } \\
\text { Earth. }\end{array}$ \\
\hline PAP/RAC, 1999 & Sustainable development is development given by the carrying capacity of an ecosystem. \\
\hline $\begin{array}{l}\text { Vander-Merwe \& Van-der- } \\
\text { Merwe, } 1999\end{array}$ & $\begin{array}{l}\text { Sustainable development is a program that changes the economic development process to ensure the basic quality } \\
\text { of life, protecting valuable ecosystems and other communities at the same time. }\end{array}$ \\
\hline Beck \& Wilms, 2004 & Sustainable development is a powerful global contradiction to the contemporary western culture and lifestyle. \\
\hline Vare \& Scott, 2007 & $\begin{array}{l}\text { Sustainable development is a process of changes, where resources are raised, the direction of investments is } \\
\text { determined, the development of technology is focused, and the work of different institutions is harmonized, thus } \\
\text { the potential for achieving human needs and desires is increased as well }\end{array}$ \\
\hline Sterling, 2010 & $\begin{array}{l}\text { Sustainable development is a reconciliation of the economy and the environment on a new path of development } \\
\text { that will enable the long-term sustainable development of humankind. }\end{array}$ \\
\hline Marin et al., 2012 & $\begin{array}{l}\text { Sustainable development gives a possibility of time unlimited interaction between society, ecosystems and other } \\
\text { living systems without impoverishing the key resources }\end{array}$ \\
\hline Duran et al., 2015 & $\begin{array}{l}\text { Sustainable development is a development that protects the environment, because a sustainable environment } \\
\text { enables sustainable development }\end{array}$ \\
\hline Bhandari 2018 & tainable development is a fundamental basis of development practice and way of thinking ahead. \\
\hline
\end{tabular}

Source: Klarin (2018:77).

This change of sustainability meaning is based on its complexity- in coverage- Economic- Social and environment and its subsidiaries. According to Daly "Standard economics defines sustainability as nondeclining utility over generations. Ecological economics considers this unworkable because utility is not measurable, and more importantly cannot be bequeathed. Also, it is throughput, not utility, that impinges on the environment. Ecological economics therefore defines sustainability as the bequest to future generations of an intact resource base, a non-declining stock of natural capital (strong sustainability). Some economists define sustainability as a non-declining total capital stock (the sum of natural and man-made capital) on the neoclassical assumption of easy substitution between the two. The usual ecological economists' view of complementarity, with natural capital being the limiting factor, argues for the nonreclining natural capital definition” (Daly, 2007: 254-255).

Primarily sustainability discourse was developed to overcome the worrisome triggered through environmental change and to search the technological tools to monitor the environmental challenges and impacts.

Table 3. The development trend-the worrisome of environmental damage and mainstreaming of sustainability

\begin{tabular}{|l|l|l|}
\hline Year & \multicolumn{1}{|c|}{ Activity } & \multicolumn{1}{|c|}{ Description } \\
\hline 1969 & $\begin{array}{l}\text { UN published the report Man and His Environment or U } \\
\text { Thant Report. }\end{array}$ & $\begin{array}{l}\text { Activities focused to avoid global environmental degradation. More } \\
\text { than 2,000 scientists were involved in creation of this report. }\end{array}$ \\
\hline 1972 & $\begin{array}{l}\text { First UN and UNEP world Conference on the Human } \\
\text { Environment, Stockholm, Sweden. }\end{array}$ & $\begin{array}{l}\text { Under the slogan Only One Earth, a declaration and action plan for } \\
\text { environmental conservation was published. }\end{array}$ \\
\hline 1975 & $\begin{array}{l}\text { UNESCO conference on education about the } \\
\text { environment, Belgrade, Yugoslavia. }\end{array}$ & $\begin{array}{l}\text { Setting up a global environment educational framework, a statement } \\
\text { known as the Belgrade Charter. }\end{array}$ \\
\hline 1975 & $\begin{array}{l}\text { International Congress of the Human Environment } \\
\text { (HESC), Kyoto, Japan. }\end{array}$ & Emphasized the same problems as in Stockholm in 1972. \\
\hline 1979 & $\begin{array}{l}\text { The First World Climate Conference, Geneva, } \\
\text { Switzerland. }\end{array}$ & $\begin{array}{l}\text { Focused on the creation of the climate change research and program } \\
\text { monitoring. }\end{array}$ \\
\hline 1981 & $\begin{array}{l}\text { The first UN Conference on Least Developed Countries, } \\
\text { Paris, France. }\end{array}$ & $\begin{array}{l}\text { A report with guidelines and measures for helping the } \\
\text { underdeveloped countries. }\end{array}$ \\
\hline 1984 & $\begin{array}{l}\text { Establishment of United Nations World Commission on } \\
\text { Environment and Development (WCED). }\end{array}$ & $\begin{array}{l}\text { The task of the Commission is the cooperation between developed } \\
\text { and developing countries and the adoption of global development } \\
\text { plans on environmental conservation. }\end{array}$ \\
\hline 1987 & $\begin{array}{l}\text { WCED report Our Common Future or Brundtland report } \\
\text { was published. }\end{array}$ & $\begin{array}{l}\text { A report with the fundamental principles of the concept of } \\
\text { sustainable development. }\end{array}$ \\
\hline
\end{tabular}


Table 3 (cont.). The development trend-the worrisome of environmental damage and mainstreaming of sustainability

\begin{tabular}{|c|c|c|}
\hline Year & Activity & Description \\
\hline 1987 & Montreal Protocol was published. & $\begin{array}{l}\text { Contains results of the researches on harmful effects on the ozone } \\
\text { layer. }\end{array}$ \\
\hline 1990 & $\begin{array}{l}\text { The Second World Climate Conference, Geneva, } \\
\text { Switzerland. }\end{array}$ & $\begin{array}{l}\text { Further development of the climate change research and monitoring } \\
\text { program and the creation of global Climate Change Monitoring } \\
\text { System. }\end{array}$ \\
\hline 1992 & $\begin{array}{l}\text { United Nations Conference on Environment and } \\
\text { Development (Earth Summit or Rio Conference), Rio de } \\
\text { Janeiro, Brazil. }\end{array}$ & $\begin{array}{l}\text { In the Rio Declaration and Agenda } 21 \text { Action Plan principles of } \\
\text { sustainable development were established and the framework for the } \\
\text { future tasks as well. }\end{array}$ \\
\hline 1997 & Kyoto Climate Change Conference, Kyoto, Japan. & $\begin{array}{l}\text { The Kyoto Protocol was signed between countries to reduce CO2 } \\
\text { and other greenhouse gas emissions, with commencement in } 2005 \text {. }\end{array}$ \\
\hline 2000 & UN published Millennium declaration. & $\begin{array}{l}\text { Declaration containing eight Millennium Development Goals } \\
\text { (MDGs) set by } 2015 \text {. }\end{array}$ \\
\hline 2002 & $\begin{array}{l}\text { The World Summit on Sustainable Development, } \\
\text { Johannesburg, South Africa. }\end{array}$ & $\begin{array}{l}\text { Report with the results achieved during the time from the Rio } \\
\text { Conference, which reaffirmed the previous obligations and set the } \\
\text { guidelines for implementation of the concept in the future. }\end{array}$ \\
\hline 2009 & $\begin{array}{l}\text { The Third World Climate Conference, Geneva, } \\
\text { Switzerland. }\end{array}$ & $\begin{array}{l}\text { Further development of the global Climate Change Monitoring } \\
\text { System with the aim of timely anticipation of possible disasters. }\end{array}$ \\
\hline 2009 & World Congress Summit G20, Pittsburgh, USA. & $\begin{array}{l}\text { G20 member states made an agreement on a moderate and } \\
\text { sustainable economy. }\end{array}$ \\
\hline 2012 & UN conference Rio +20 , Rio de Janeiro, Brazil & $\begin{array}{l}\text { Twenty years from the Rio conference, report the future we want } \\
\text { renewed the commitment to the goals of sustainable development } \\
\text { and encouraged issues of the global green economy. }\end{array}$ \\
\hline 2015 & $\begin{array}{l}\text { UN Sustainable Development Summit 2015, New York, } \\
\text { SAD. }\end{array}$ & $\begin{array}{l}\text { The UN } 2030 \text { Agenda for Sustainable Development was published, } \\
\text { setting up } 17 \text { Millennium Development Goals which should be } \\
\text { achieved by } 2030 \text {. }\end{array}$ \\
\hline 2015 & $\begin{array}{l}\text { UN conference on climate change COP21Paris Climate } \\
\text { change Conference, Paris, France. }\end{array}$ & $\begin{array}{l}\text { Agreement on the reduction of greenhouse gases in order to reduce } \\
\text { and limit global warming. }\end{array}$ \\
\hline
\end{tabular}

Source: UN 2015; UNFCCC, 2016 (recited from Klarin 2018:72).

The environmental change detection was only possible through the technological enhancement and use of enhanced tools to detect the change. If we go even back, we can find, how, the Greek began to explore the position of the Earth and atmospheric variation through Geology and Geography (Geology: Greek meaning Earth and its speed and Geography (Tuan1991) "ge" for earth and "grapho" for "to write"); from where the exploration of climate variation and change came into the research agenda. The concern about the environmental change can be seen from the Greek Era; however, it was only within a certain group of people. The geological and geographical study of the Earth's system paved the ground for research on scenarios of climate variation; these are the oldest disciplines of the academic world. Longwell (1954) examines the root of the geological exploration - the first step in the detection of environmental change (Bhandari 2017). However, the concerned people were only elites / scholars and scientists. Historically, we can find many concerned scientists about the impact of environmental damage on human, however, it was also subject of discussion at the political arena. "The history of life on earth has been a history of interaction between living things and their surroundings ... Considering the whole span of earthly time, the opposite effect, in which life continually modifies its surroundings, has been relatively slight. Only within the moment of time represented by the present century has one species - man - acquired significant power to alter the nature of his world." (Rachel Carson, Silent Spring, 1962).

In the modern era, 1972 was the milestone year for the institutionalization of environmental concern and sustainability discourse formalization, through the first World Conference on Global environment, which recommended establishing the United National Environment Program. Similarly, the Club of the Rome also published its most authentic report "The Limits to Growth" (1972), which draws global attention to the global environment. There is no direct challenge on the research outcome of the Rome Club. The "Limits to Growth" report states that if the present growth trends in world population, industrialization, pollution, food production and resource depletion continue unchanged, the limits to growth on this planet will be reached sometime within the next one hundred years (Bhandari, 2012). The most probable result will be a rather sudden and uncontrollable decline in both population and industrial capacity. This was a second shock after Rachel Carson's book Silent Spring (1962), which largely drew the attention of the general public regarding the seriousness of global climate change (Brechin and Bhandari 2011). Having growing concerns and evidence of global impact of environment, UNEP continued its consultation with the scientific and government agencies to reach a mutual understanding.

"Human history has traditionally been cast in terms of the rise and fall of great civilizations, wars, and specific human achievements. This history leaves out the important ecological and climate contexts that shaped and 
mediated these events. Human history and earth system history have traditionally been developed independently... and there have been few attempts to integrate these histories ... across these fields of study" (Robin and Steffen, 2007: 9). The environmental history helps to pave the future direction through its failure or success stories.

It is established notion that the sustainability discourses emerged very recently, however, it has long route to be accepted in the main stream of political, social, economic and environmental agendas. The growth of international concern of governments, scientific agencies, non-profit sector and general public dealing with the environment began to accelerate from the beginning of the $20^{\text {th }}$ century and still continues. The sustainability discourse is uniformly accepted, used, and being utilized.

The sustainability discourse became so paramount that, it has its own niche in development arena of current time. It can be state that, discourse became an established, accepted principle, in another words, it can be seen as sustainability regime. "Regime is sets of implicit or explicit principles, norms, rules and decision-making procedures around which actors' expectations converge in a given area of international relations" (Krasner, 1983). Maintaining the Sustainability is national, transnational, multinational and global concern. Socioeconomic and environment problems have been increasing on a global scale (HIVAID, inequality, transnational migration, terrorism, environmental problems-climate change etc.), and these problems themselves create certain types of regime and format their own networks and relationships.

In current scenario, sustainability discourses are seen in the form of agreement on the facts, norms, rules, and procedures. The United Nations has been playing a critical role in sustainability regime formation with factual scientific results and is influential in international policy formation to obtain the sustainable development goals.

In this regard, it is necessary to understand that "discourse is not a neutral medium for the formation and transfer of values, meanings and knowledge that exist beyond its boundaries, rather, it is constitutive of them. That is, discourse is not best understood as an innocent reflection of non-linguistic meaning, nor simply in terms of the intentions of language users. Rather, discourse constructs meaning. Though material objects and social practices have a material existence outside of language, they are given meaning or 'brought into view' by language and are thus discursively formed. Discourse constructs, defines and produces the objects of knowledge in an intelligible way while excluding other forms of reasoning as unintelligible. It structures which meanings can or cannot be deployed under determinate circumstances by speaking subjects" (Barker 2004:54). In relation to sustainability discourse, sustainability is no more a word with complex meaning, however, it is the framework of maintaining the "development that meets the needs of the present without compromising the ability of future generations to meet their own need" (Our Common Future 1987). And how, the sustainable development goals (SDGs) are the pathways and various policies are the directives and countries plans are the future directives. The goals are set with the past experience of millennium development goals implementation's (MDGs) output. As such MDGs was only partial success; SDGs has incorporated the shortfalls of past and created the future directives through 17 goals and 100s of policy directives.

Sustainability is a complex issue which is built on the necessity created by the over utilization of natural resources, due to accelerated development intervention on nature. As Costanza et.el. (2007) note "the most remarkable phenomenon on Earth in the 20th century was the "Great Acceleration" the sharp increase in human population, economic activity, resource use, transport, communication and knowledge-science-technology that was triggered in many parts of the world...following World War II and which has continued into this century... Other parts of the world, especially the monsoon Asia region, are now also in the midst of the Great Acceleration. The tension between the modern nation state and the emergence of multinational corporations and international political institutions is a strong feature of the changing human-environmental relationship. The "engine" of the Great Acceleration is an interlinked system consisting of population increase, rising consumption, abundant cheap energy, and liberalizing political economies" (Costanza et. al., 2007:4 as cited in Robin and Steffen, 2007:7). The anthropogenic disturbance in nature has been its acceleration and impact on planet's environment were drawing attentions of concerned stakeholders. This urgency was documented (one can state them as sustainability discourses at large), in various forms i.e. research papers, books, monographs, thesis, dissertation etc.(IUCN, 1980; Paehlke, 1989; Eckersley, 1992; Litfin, 1994; Hajer, 1995; Dryzek, 1997; van Dijk, 1998; Sawyer, 2002; Palmer, 2003; Barker, 2004; Diamond, 2005; Costanza et.al., 2007; Lorek and Fuchs, 2011; Veen, et. al., 2013; James, 2015; Tahvilzadeh et. al., 2017, etc.). The Silent Spring (1962); The Limits to Growth"(1972); World Conservation 
Strategy (1980); Our Common Future, (1987) and many UN and other agencies world summit on earth (19722012) on sustainability discourse.

In addition, other major treaty events which boasted the sustainability discourses are Ramsar Convention, Stockholm Declaration of the United Nations Conference on the Human Environment, The Rio Declaration on Environment and Development, Convention on Biological Diversity ,Convention on Long-Range Trans-boundary Pollution, Convention on the Prevention of Marine Pollution by Dumping of Wastes and Other Matter, Convention on International Trade in Endangered Species(CITES), Basel Convention on the Control of Trans-boundary Movements of Hazardous Wastes and Their Disposal, Convention Concerning the Protection of the World Cultural \& Natural Heritage, United Nations Convention to Combat Desertification, United Nations Convention on Law of the Sea (UNCLOS), United Nations Framework Convention on Climate Change and the Kyoto Protocol on Global Warming and many others). These treaty events captured the notion of international multicultural and socioeconomic politics. Many researchers have examined the successes and failures of international treaties and agreements. These researches accept the role and responsibilities of nation, international organizations, civil societies, NGOs and advocacy group. The hegemonic power relationship is still in force within the current neoliberal world (Bhandari, 2018).

However, the major step in fostering sustainability begins from the first UN Conference on the Human Environment, Stockholm (1972), followed by the second Earth Summit in Rio de Janeiro 1992, where 172, 108 people participated including head of the states, business personnel and other experts. In the first time about 2,400 representatives of non-governmental organizations (NGOs) participated in Rio summit. Summit produced agenda 21 declaration on environment and development, the statement of forest principles, the United Nations framework convention on climate change and the United Nations convention on biological diversity. Since Rio summit global concern on environment management and policy reform became common agenda to the entire world. Most of the states in the world started focus and monitor on patterns of production (i.e. toxic components, gasoline, and poisonous waste), investigation on alternatives for the fossil fuels (which is major cause for global climate change), alternatives for the public transportation (to reduce air pollution and smog) and water resource management. Blue print provides a comprehensive structure for the modernization of national / transnational environment protection and environment reform which includes the framework for sustainability and offers the links between economic growth using science and technology to solve the environmental problems with the application of multi-driven approaches. The world conferences based on sustainability and environmental reforms have been broadly focusing on the natural resource management, searching options to reduce the environment impact due to economic activities with the application of new technology. As a result, sustainability discourse became a prime field of consideration in the development agendas of global concern.

In sum, agenda of sustainability is institutionalizing, blue prints are becoming common and nations are more receptive to address the socioeconomic, and environment problem and the diffusion of such concern is accelerating.

\section{What are the boundaries of Sustainability?}

In general term, the word meaning of boundaries can be understood as a limitation, edge, or limit. According to Cambridge English Dictionary-an edge or limit of something, the limit of a subject or principle, or can be understood as administrative boundary, natural boundary, or certain range within or beyond the limit. As seen in the synonyms the term boundary is that which has a limitation. However, connecting with the sustainable development which is defined as "Sustainable development is development that meets the needs of the present without compromising the ability of future generations to meet their own needs" (Brundtland, 1987).

As noted in the above question (discourse of sustainability), the global focus on sustainability began in earnest with the 1980 publication of the World Conservation Strategy by the International Union for Nature and Natural Resources (IUCN). The World Conservation Strategy is the first warning of resources limitation in another worldthere a limitation or boundary and societal including, social, economic and environmental development should not cross the boarders. This bold statement highlighted the scope and limitations (boundaries) of our planet's natural resources and ecological systems. Though it presented a great scope of future development with the wise use of available resources, it also presented a scenario how humankind's current and future uses of resources would diminish the carrying capacities of our ecosystems. Though neoliberalists might disagree with the arguments of limiting carrying capacity in view of the new innovative measures, the Brundtland Commission on Sustainable Development (CSD) in 1987 had realized the possibilities of deteriorating ecosystem services, if the present trend of resource consumption continues without alternatives. It even coined the term of sustainable development (SD) 
for the wise of resources so as to ensure their availabilities for future generations. The Brundtland report gained much importance in the UN Conference on Environment and Development (UNCED) in Rio de Janeiro in 1992. Agenda 21 of this UNCED emphasized much on the sustainable aspect of ecosystem services. Since then SD got more importance both in concept and practice. Today, the UN and its agencies are embedding the term SD in each of their activities as envisioned by the CSD (Bhandari, 2017; 2018).

As listed in the table 3, in 1969 UN published the report Man and His Environment or U Thant Report, which first outlined the environmental damage and its impact and proposed the activities focused to avoid global environmental degradation. This indicated that over use of natural resources is crossing the boundary or limitation. And all efforts through United Nations, international development agencies, international intergovernmental, nongovernmental organization, and warning calls from scholars (through publications, seminars presentations, dissertations, etc.) have been trying to aware society, showing evidences that anthropogenic activities negatively impacting on environment. In 1987, WCED report Our Common Future or Brundtland report was published, which paved the fundamental principles of the concept of sustainable development, provided the clear indication that, if we continue what we are doing on the name of economic development (this is beyond the limit of nature), future generation may not have natural privilege as we have now. As depicted in the table 3 above, 1972, a declaration and action plan for environmental conservation, 1975 conference on education about the environment, 1975 summit on Human Environment, 1992, Conference on Environment and Development, 2000-Millennium declaration, 2002 on Sustainable Development, 2012-conference Rio +20, 2015-Sustainable Development Summit, which set up 17 Millennium Development Goals and 2015- COP21Paris Climate change Conference (holding the increase in global average temperature below $2{ }^{\circ} \mathrm{C}$ or $1.5^{\circ} \mathrm{C}$ above pre-industrial levels), all focused on environmental damage hampering earth sustaining mechanisms and earliest action has to be taken and implemented. The agenda 21, Millennium Development Goals, and the most recent one sustainable development 17 goals and 169 targets to achieve them are the framework problems illustrations and plans for not to cross the boundaries and maintain the health of planet as well as resolve the challenges of "poverty and hunger everywhere; to combat inequalities within and among countries; to build peaceful, just and inclusive societies; to protect human rights and promote gender equality and the empowerment of women and girls; and to ensure the lasting protection of the planet and its natural resources....resolve also to create conditions for sustainable, inclusive and sustained economic growth, shared prosperity and decent work for all, taking into account different levels of national development and capacities (UN 2015-https://sustainabledevelopment.un.org/post2015/transformingourworld). This warning and the call of action to resolve the problems, the sustainable development is proposed method, plan of action and procedures of implantation. The underline assumptions here is the current development which mostly based on exploitation of nature and natural resources need to shift towards the harmony with nature. Therefore, the boundaries of sustainable development largely seen through environmental constraints ("carrying capacity", "sustainable consumption and production", "guardrails", "tipping points", "footprints", "safe operating space" or "planetary boundaries") (Rockström et. al., 2009; 2013:3).

Table 4. Planetary boundaries and quantification

\begin{tabular}{|l|l|}
\hline \multicolumn{1}{|c|}{ Planetary boundary } & \multicolumn{1}{|c|}{ Boundaries quantified } \\
\hline 1. Climate change & $\begin{array}{l}\mathrm{CO} \text { concentration in the atmosphere should be limited to 350 ppm and/or a maximum change of +1 } \\
\mathrm{W} \mathrm{m}-2 \text { in radiative forcing }\end{array}$ \\
\hline 2. Biological diversity loss & An annual rate of a maximum of 10 extinctions per million species \\
\hline 3. Biogeochemical cycles & $\begin{array}{l}\text { Nitrogen (N) cycle - limit industrial and agricultural fixation of } \mathrm{N} 2 \text { to 35 Mt N yr-1) Phosphorus (P) } \\
\text { cycle (annual P inflow to oceans not to exceed 10 times the natural background weathering of P }\end{array}$ \\
\hline 4. Global freshwater use & Limited to 4000 km3 yr-1 of consumptive use of runoff resources \\
\hline 5. Land system change & Not more than 15\% of the ice-free land surface used as cropland \\
\hline 6. Ocean acidification & $\begin{array}{l}\text { Mean surface seawater saturation state with respect to aragonite at not less than 80\% of pre-industrial } \\
\text { levels }\end{array}$ \\
\hline 7. Stratospheric ozone & Maximum 5\% reduction in O3 concentration from pre-industrial level of 290 Dobson Units \\
\hline 8. Chemical pollution & No boundary defined \\
\hline 9. Atmospheric aerosol loading & No boundary defined \\
\hline
\end{tabular}

Source: Rockström, et.al. 2013:26-27- "The planetary boundary framework below is based on a decade's research suggesting a safe operating space for humanity. This was brought forward as a priority in the report from the UN Secretary-Generals High Level Panel "Resilient People Resilient Planet" (UNs Secretary General's High-Level Panel on Global Sustainability 2012). It stated that we should "defend the science that shows we are destabilizing our climate and stretching planetary boundaries to a perilous degree" (25). Rockstrom et.al. (2013:21) summarize (1) The science of planetary boundaries makes clear that we are on an unsustainable trajectory; (2) Achieving the Sustainable Development Trajectory will require an unprecedented global effort by all countries - rich and poor - that will only be possible under a shared global framework for sustainable development. The planetary boundary image by Rockström et. al. (2009) gives clearer picture with same circumstances. 


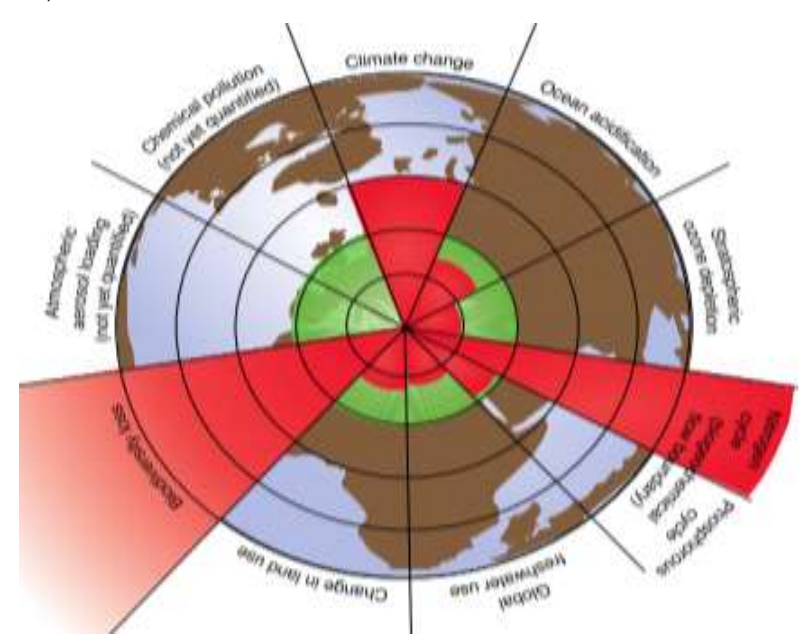

Figure 2. Planetary boundary

Source: Rockström et. al. (2009) and also in Steffen et al. (2015: 736) as cited also in Stockholm Resilience Centre website www.stockholmresilience.org (Estimates of how the different control variables for seven planetary boundaries have changed from 1950 to present. The green shaded polygon represents the safe operating space.); The red areas in image 1. show the position of each boundary. The safe operating space for the boundaries is within the green area. Out of these nine boundaries at least three have already been passed: climate change, biodiversity loss, and the nitrogen cycle.

The boundaries of sustainable development can also be seen in terms of its three-pillar infusion-social, economic and environmental. The environmental boundary is depicted in the table 3, many scientist / scholars have shown the interrelationship of sustainability planetary boundary (Barnosky, 2012; Steffen et. al., 2011; Carpenter and Bennett, 2011; Cornell, 2012; Erb et. al., 2012; Foley et. al., 2011; Folke et. al., 2011; Folke and Rockström, 2011; Ingram, 2011; Rockström and Karlberg, 2010; Running 2012, etc.). There is gap of research on sustainability boundary setting with the social, economic, cultural and political lenses.

Social boundaries of sustainability can be seen at individual, family, and cultural differences and their relationships, how they perceive sustainability in their pursuits. Understanding of sustainability awareness can be seen at the individuals to the societal level, - the aware about own Ecological footprint; carrying capacity of local niche; valuing the nature on social interactions - regular behavior pattern - waste disposal system or water use pattern etc. shows the regular pattern of understanding of sustainability through behavior. The conflict among societies in resource use and utilization, the social strata and cultural variations are also among the other boundaries of social phenomena. Economic boundaries of sustainability can be seen in the eyes of the victims of poverty and hunger, in the inequalities within and among countries. Politically boundaries of sustainability are a whole different scenario of discussion. The major cause of the conflict, division, wars, segregation, separation, ............ are major boundaries. Table 2, development scenarios of sustainable development can be considered as the minimizing the boundaries impacts and take action collectively to resolve the environmental, social and economic challenges world is facing. UN 2015, in Transforming our world: the 2030 Agenda for Sustainable Development states that "determined to mobilize the means required to implement this Agenda through a revitalized Global Partnership for Sustainable Development, based on a spirit of strengthened global solidarity, focused in particular on the needs of the poorest and most vulnerable and with the participation of all countries, all stakeholders and all people" (Transforming our world: the 2030 Agenda for Sustainable Development-UN 2015). As noted in Scoones, (2016), 'there has been a growing consensus on the end points of sustainability, combining environmental, social, and economic goals - now parsed in terms of circular, low-carbon, or green economies - there has been less discussion of how to get there and of the social, cultural, institutional, and political challenges that arise' beyond the national and political boarders. The Sustainable Development 17 Goals and 169 Targets (UN 2015) presents the current scenario of the problems (which shows where the current trend of developed crossed the boundary) and provides the pathway to move forward.

The boundaries of sustainable development can be seen, analyzed and interpreted within the coverage of Sustainable development goals (1: No Poverty; 2: Zero Hunger; 3: Good Health and Well-being; 4: Quality Education; 5: Gender Equality; 6: Clean Water and Sanitation; 7: Affordable and Clean Energy; 8: Decent Work and Economic Growth; 9: Industry, Innovation and Infrastructure; 10: Reduced Inequality; 11: Sustainable Cities and Communities 12: Responsible Consumption and Production; 13: Climate Action;14: 
Life Below Water 15: Life on Land;16: Peace and Justice Strong Institutions; 17: Partnerships to achieve the Goal) (UN 2015) and beyond. These goals are interconnected, multidimensional and have underline constraints (each holds different boundary discourse of sustainable development) (Rockström et. al., 2013).

The boundaries of sustainable development can also be seen and evaluated in terms of institutionalization process and organizational process. In so far, sustainability is formalized, organized and institutionalized frame of development paradigm (Anaedu and Lars-Goran 2002; Bertelsmann Stiftung and Sustainable Development Solutions Network 2018; Robert et. al. 2005; Maser 1997), therefore, the boundaries of sustainable development can also be evaluated in terms of formal organization. "Formal organizations are typically understood to be systems of coordinated and controlled activities that arise when work is embedded in complex networks of technical relations and boundary-spanning exchanges. But in modern societies, formal organizational structures arise in highly institutional contexts. Organizations are driven to incorporate the practices and procedures defined by prevailing rationalized concepts of organizational work and institutionalized in society. Organizations that do so increase their legitimacy and their survival prospects, independent of the immediate efficacy of the acquired practices and procedures. There can develop a tension between on the one hand, the institutionalized products, services, techniques, policies, and programs that function as myths (and may be ceremonially adopted), and efficiency criteria on the other hand. To maintain ceremonial conformity, organizations that reflect institutional rules tend to buffer their formal structures from the uncertainties of the technical activities by developing a loose coupling between their formal structures and actual work activities" (Meyer and Rowan, 1977). In terms of sustainability the structured rules, directives and articulative principles can be seen as the boundaries of sustainable development. The notion of complexity of organization applies in the context of sustainable development. As sustainability is integral part in resolving the constraints of developmental discourses and have various challenges in maintaining interrelation boundaries of social, economic and environmental connections. "The most effective organizations achieve a degree of differentiation and integration in organizational boundary-spanning functions which is compatible with environmental demands" (Lawrence \& Lorsch, 1967). The sustainable development boundary is thin if worked with the multinational, multidimensional and at the scholarly level multidisciplinary approaches. However, addressing boundary? ... essential to explore more to pave the future direction.

To outline boundary of sustainable development is tremendously difficult because of its complexity, coverage and multicriterial nature in development paradigms. The boundaries of sustainable development shifts as the SDG are achieved. As UN 2015 in Transforming our world: the 2030 Agenda for Sustainable Development notes "a call for action by all countries - poor, rich and middle-income - to promote prosperity while protecting the planet. They recognize that ending poverty must go hand-in-hand with strategies that build economic growth and address a range of social needs including education, health, social protection, and job opportunities, while tackling climate change and environmental protection'. As measurable outcomes are visible the boundary will change (Bhandari 2018). The boundary and definition of sustainable development changes with the advancement of epistemology of sustainability. As Hannan and Freeman (1989) state 'the boundary definition of organizations is itself a variable that changes as technology and other environmental forces affect it. Determining how to exactly classify a particular organization is becoming increasingly more difficult'. This notion completely applies with the complexity notion of sustainability and also useful for boundary setting.

Sustainable development complexity can be analyzed through the organizational theoretical lenses in three level - 'first organizations are complex because of complex adaptive systems, differentiations in agents, variations on decision making and problem solving techniques and networks, information technology and algorithmic complexity, second, organization hold complex adaptive systems, loose coupling and models, edge of chaos, simple rules and complex behavior, emergence and recombination and evolution and thirdly, organizational interdependence, cellular automata, micro-behavior and macro-structure complex inter-organizational dynamics, sensitivity to initial conditions and path dependence (Baum and Rowley, 2005). Adaptation of sustainable development - in multisectoral development has pass / experience through complex adaptive systems, because each country has difference social, cultural, geographical and political limitation or boundaries. The complexity also exists in decision making system because each countries definition of public participation may differ due to their own governance system. 


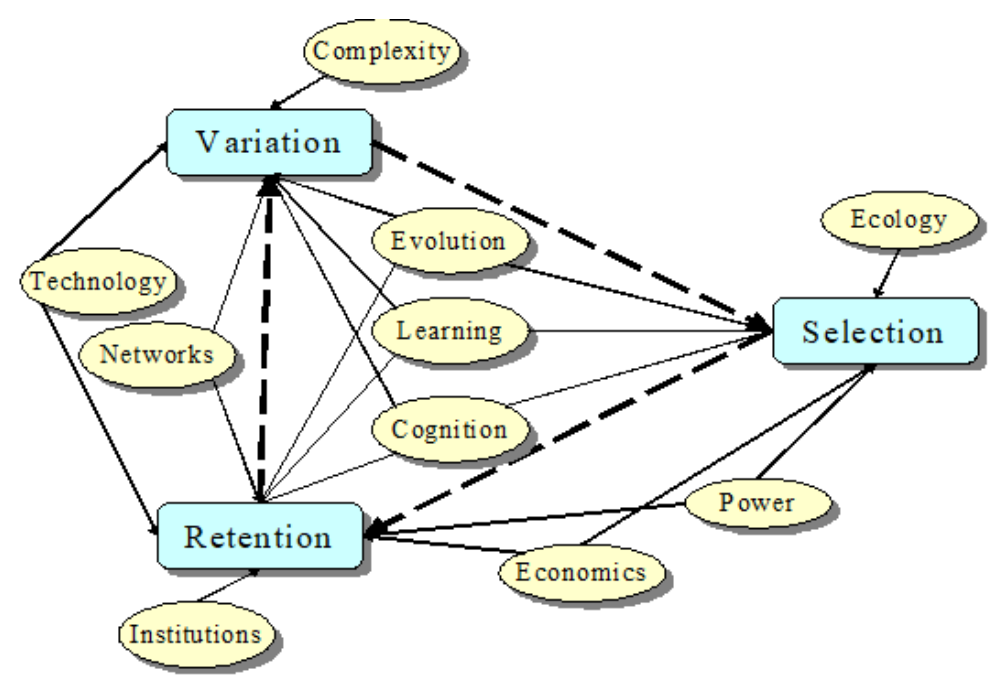

Figure 3. The depiction of meta-frame of organization

Source: Baum and Rowley (2005).

Baum and Rowley (2005) depiction of meta-frame (flow chat 1) of organization can be helpful to see the complexity structures of sustainable development. However, there is the need of modification on the basis of sustainability parameters. The implementation and evaluation of sustainable development perspectives depends on how sustainability principles (in current scenario SDGs goals and targets) are interrelated with each other and how this complexity can be minimized. There is research gap on sustainability complexity and its boundaries. The sustainability boundaries also be evaluated with the lenses of institutional perspectives; which is another field of further research. As nicely illustrated in Pesch (2014) descriptions of institutional domains on the one hand and of second-order problems that are related to these domains on the other hand, we may conclude that we are faced with a dilemma in case of promoting sustainable development. In its very essence, sustainable development pertains to problems that transcend the boundaries of institutional domains. To resolve environmental degradation and the depletion of resources, we have to fulfill the following necessities: appropriate knowledge has to be produced; the external effects of our economic system have to be integrated into private transactions, having major effects for the distribution of economic wealth and economic burdens; effective collective decisions have to be made that transcend national boundaries and that are subject to broad societal consent; and the creation and implementation of sustainable technologies have to be facilitated. In all, the tendencies of institutional domains to displace goals have to be overcome (Pesch, 2014: 48).

Sustainable development boundaries can be obstacles to achieve the progress and there is need of new policy formation which can create instruments to promote boundary-crossing collaborations, to achieve the sustainable development goals. "Understanding how best to move along the road toward sustainability, as contrasted with understanding the levels and types of unsustainability, is an issue that has not yet been addressed in detail. Sustainability is a systems problem, one that defies typical piecemeal approaches such as: Will there be enough ore in the ground for technological needs? Will there be enough water for human needs? How can we preserve biodiversity? Can global agriculture be made sustainable? (Graedel and Voet, 2010: 3). This concern of Graedel and Voet (2010), provides another gap of sustainability discourse; however, the efforts to answer the posed questions provides the path way to the scholarly world. In advancing sustainable development epistemology, each stakeholder has unavoidable role and responsibility, however, core responsivities lie to higher educational institutions (Wallendorf, 1989; Yao and Bai, 2008; Waheed et.al., 2011; Yarime and Tanaka 2012; Versteijlen et.al., 2017).

'The boundaries of the sustainability system are determined by four dimensions based on the finiteness of the fossil energy system, the development of a post-fossil energy system, the problem of climate change, and the chosen sustainability paradigm. This sustainability approach could enable sustainable development 
opportunities for the present generation without affecting the welfare of future generations' (Schlor et al., 2015:52).

The sustainable development notion provides the hope in the world, by reviving security in the society, providing the environment to share and cope with problems and produce goods, deliver services, maintain order, and gives a way to survive from individual level to societal stage. The sustainability notion hopes to minimize the challenges, helps to establish order in the society (Richter, 2009; Meuleman, 2013). In relation to linkage with day to day individual and societal settings the SDGs are the fundamental building blocks of modern societies, and the basic vehicles through which collective action is being undertaken. The eminence of sustainable development discourses is new paradigms of modern world and it is obvious to be prepared to face various consequences particularly in implementation, since there are limitless boundaries has to identified and addressed. Sustainability notion has to cross various isomorphism processes which creates boundaryspanning demands for economic development (Bhandari, 2018). Further to achieve the sustainable development goals, the concern stakeholders have to incorporate structural elements isomorphic process (which will create more boundaries) to address the complexity and interdepend boundaries.

\section{What are the linkages with creativeness and sustainability?}

"Truth reveals itself in degrees, and we can progress from an incomplete to a more and ever more complete comprehension of truth. Truth is not a thing, not an object that we either have in entirety or have not at all." Johann Wolfgang von Goetфhe (1749-1832)

"Creativity is understood as the human capacity, through imagination or invention, to pro use something new and original in order to solve problems. It is a unique and renewable resource. Creativity enables individuals to expand their abilities and develop their full potential. In today's global, knowledge-based societies, creative assets are generating new forms of revenue and employment that are spurring growth, in particular among youth. Releasing diverse sources of inspiration and innovation, creativity contributes to building open, inclusive and pluralistic societies. As a multi-faceted human resource that involves processes, environments, persons and products, creativity can inspire positive transformative change for future generations. Creativity, embracing cultural expression and the transformative power of innovation, can contribute to finding imaginative and better development outcomes" (UNESCO 2013:1-2).

The notion of sustainability and creativity has interchangeable, interrelated and interdepended relationship. In sustain is the difficulties, the living being adopt with the surroundings and sustain according to the exiting or changing environment. The survival with the fittest notion can work here at the biological environment. When social dimension is involved, the survival with the fittest still exits, however, it goes further on searching on options of survival. We can see these characteristics among the animal species of various ecosystems. If we look back to the human development and evolution, at least from the primitive society to modern society we can see how adoptability was developed by human to survive and how creativity was applied in process of survival and development.

The notion of sustainability through creativity has long history as history of human survival and development. However, at least in terms of the concept and applicability we can track as back as the written history was began. The development process was to some extend in the planet until the industrial revolution began. The notion of development changed to competition with nature and the human creativity actually disturbed the natural process to co-exist and development. The human creativity to sustain began to dominant nature.

Many countries have been working on how to continue economic growth without harming the environment, as pathway the concept of sustainable development (SD) has been discussed and utilized since last two decades or so. Green Economy (GE) and the Creative Economy (CE) initiative initiated by two United Nation (UN) agencies, UN-Environment Program (UNEP) and UN-Conference on Trade and Development (UNCTAD), try to capture the notion of the vulnerability of human welfare, caused by the degradation of global environment, which can be understood as the result of the widespread application of an unsustainable model of economic development; however still is A fuzzy assumption- in attaining the global sustainability .The Green Economy (GE), which can be consider a part of creativity, do not alter with SD, however, provides further steps practically and theoretically. This training program aims to provide theoretical and practical 
aspects of GE and equip participants to be able to prepare strategic plan for green growth and skilled them for professionalism and effectiveness in the performance of their duties in their respected organizations.

Both initiatives capture concerns raised over the past 40 years to address climate change to frame the treaty agreements. The establishment of the IPCC, UNFCC, Kyoto Protocol, and Clean Development Mechanism are among notable outcomes. One can take GE and CE initiates as untested tools that assume too much about greening as an engine for growth, sectoral opportunities, hurdles and enabling conditions, the value of ecosystems and biodiversity, and the vicious cycle of environmental losses and persistent poverty. Both GE and CE emphasize green industry and business, but they lack means to provide the know-how to perceive global economic growth. GE and CE also fail to address strategic uncertainty such as: the likelihood of adverse effects; the consequences of change; the speed of change; discontinuities; and especially uncertainty over the effectiveness of policy instruments.

Both GE and CE initiatives are silent on how social and institutional capital can be enhanced and how creativity can be fostered. I argue that to overcome these problems, there is a need for existing structures to evolve and to create a new institutional framework which can coordinate and manage activities of all related stakeholders. It requires an effective institutional structure, strong policy, and framework for policy implementation and can work effectively, efficiently, equitably and transparently. To frame this, one need to define a new, innovative and ambitious architecture which can foster social capital.

Many scholars have tried to examine the creativity and sustainability /sustainable development (Giddings et.al., 2002; Callanan and Ferguson, 2015; Mitchell and Walinga, 2017; Basadur, Gelade and Basadur, 2014; Cheng, 2018; Corral-Verdugo et. al., 2009; Bhandari, 2017, 2018). The table 4, adopted from Mitchell and Walinga (2017: 1875), provides some glimpse of how creativity is applied in sustainability.

Table 5. Examples of factors facilitating creativity for sustainability

\begin{tabular}{|l|l|}
\hline \multicolumn{1}{|c|}{ Factors facilitating creativity } & \multicolumn{1}{c|}{ Applied to sustainability } \\
\hline Stimulating and rewarding curiosity and exploration. & Creating a comfortable and non-threatening environment. \\
\hline Building internal motivation. & $\begin{array}{l}\text { Designing an environment that supports and rewards sustainability } \\
\text { focused ideas and solutions. Leaders may motivate creative thinking } \\
\text { by getting employees to identify with a vision. }\end{array}$ \\
\hline $\begin{array}{l}\text { Building confidence and willingness to take risks: } \\
\text { eliminating defensiveness and self-doubt; building } \\
\text { favorable self-perception. }\end{array}$ & $\begin{array}{l}\text { Fostering recognition and awareness of self-doubt. Using } \\
\text { brainstorming techniques. }\end{array}$ \\
\hline $\begin{array}{l}\text { Encouraging divergent thinking: fluency and } \\
\text { flexibility in thinking. }\end{array}$ & $\begin{array}{l}\text { Utilizing thinking aids that facilitate the application of divergent } \\
\text { thinking and elicitation of new ideas. }\end{array}$ \\
\hline $\begin{array}{l}\text { Encouraging acquisition of domain specific } \\
\text { knowledge. Relevant knowledge is a prerequisite for } \\
\text { creative functioning. }\end{array}$ & $\begin{array}{l}\text { Fostering more sustainability-specific knowledge. The more } \\
\text { sustainability knowledge and expertise an individual posse, the more } \\
\text { he/she is likely to generate sustainable solutions and ideas. }\end{array}$ \\
\hline $\begin{array}{l}\text { Encouraging openness to ideas. } \\
\text { Challenging prejudgments and using different domains of knowledge, } \\
\text { analogies, metaphors, and exercises in imaginative play. }\end{array}$ \\
\hline $\begin{array}{l}\text { Encouraging building on, or combining ideas from } \\
\text { others. }\end{array}$ & $\begin{array}{l}\text { Sharing sustainability ideas can stimulate members of a group or } \\
\text { network to think of other even more novel or radical ideas. }\end{array}$ \\
\hline
\end{tabular}

Source: Mitchell and Walinga. 2017:1875.

Quantifying creativity is not easy, however, through economic parameters quantifiable or visual outcome can be drawn. As Giddings et. al. (2002) note "the economy is often given priority in policies and the environment is viewed as apart from humans. They are interconnected, with the economy dependent on society and the environment while human existence and society are dependent on, and within the environment. The separation of environment, society and economy often leads to a narrow techno-scientific approach, while issues to do with society that are most likely to challenge the present socio-economic structure are often marginalized, in particular the sustainability of communities and the maintenance of cultural diversity" (Giddings et.al. 2002:187). Here, the notion of green economy, creative economy, ecosufficiency and sustainable development broadly aimed to forester the global economy without hampering the earth ecosystem and boost social justice. According to the UNEP (2010), social justice may include: 1) not compromising future generations' capability to meet their needs; 2 ) the rights of poor countries and poor people to development and the obligations of rich countries and rich people to changing their excessive consumption levels; 3 ) equal treatment of women in access to resources and opportunities; and 4) ensuring decent labor conditions. Additionally, issues of good governance and democracy are also seen as critical for ensuring social justice and equity (UNEP 2010:2). 
Another way of looking creativity can be as Callanan and Ferguson (2015) note "Creativity. We hack it. We map it. We study it. We rate it. We take it places. We build industries around it. We invest in it. We recognize we need it, even when it hurts. We know our future depends on it... Creativity is the spark. When the spark catches, it catalyzes an expression, an experiment, a "creation." If the spark turns into an invention, an entrepreneur can build an enterprise around it" Callanan and Ferguson (2015). This can be seen in different phases, ie. Generating, conceptualization, optimizing and implementation, table 3 (Basadur, Gelade, and Basadur, 2014).

Table 6. Different phases of creativity

\begin{tabular}{|l|l|}
\hline $\begin{array}{l}\text { Quadrant IV } \\
\text { Implementing creating options in the form of actions that get } \\
\text { results and gaining acceptance for implementing a change or a } \\
\text { new idea. }\end{array}$ & $\begin{array}{l}\text { Quadrant I } \\
\text { Generating creating options in the form of new possibilities- } \\
\text { new problems that might be solved and new opportunities that } \\
\text { might be capitalized upon. }\end{array}$ \\
\hline $\begin{array}{l}\text { Quadrant III } \\
\text { Optimizing creating options in the form of ways to get an idea } \\
\text { to work in practice and uncovering all the factors that go into } \\
\text { a successful plan for implementation. }\end{array}$ & $\begin{array}{l}\text { Quadrant II } \\
\text { Conceptualizing creating options in the form of alternative } \\
\text { ways to understand and define a problem or opportunity and } \\
\text { good ideas that help solve it. }\end{array}$ \\
\hline
\end{tabular}

Source: Basadur, Gelade, and Basadur, (2014:82).

Sustainability and creativity have strong interconnections. In another word, to maintain

Sustainability, creativity, innovation, improvement and empowerment of all concern stakeholders is necessary.

"Any group that attempts to manage a common resource (e.g., aquifers, judicial systems, pastures) for optimal sustainable production must solve a set of problems in order to create institutions for collective action; there is some evidence that following a small set of design principles in creating these institutions can overcome these problems" (Elinor Ostrom, 1990).

According to UNESCO (2013), "Creativity is understood as the human capacity, through imagination or invention, to pro use something new and original in order to solve problems. It is a unique and renewable resource. Creativity enables individuals to expand their abilities and develop their full potential. Similarly, sustainability can be understood as the "development that meets the needs of the present without compromising the ability of future generations to meet their own need" (Our Common Future, 1987). How meets the needs of the present with minimal or without out harming the nature? The millennium development goals were the attempt to minimize the anthropogenic disturbances on nature and natural resources. However, they were not quantifiable and evaluation mechanism was not strong enough. The Sustainable Development Goals (which has 17 major goals and 100s of targets), has established rigorous way of program planning, and implementation with clear evaluation process.

Creativity and sustainability are intertwingled. Moreover, sustainability can only be attained properly, when concern stakeholders incorporate the innovation, cooperation beyond the political boundaries, with the involvement of governments, enterprises, research institutions, public bodies, civil society associations, financial institutions and other related bodies (Fusco 2010). To achieve the goals of sustainability, proper mechanism of evaluation process, as well as institutional arrangements needs to be implemented.

\section{What is the institutional architecture to attain the SDGs?}

"Institutions are not static; and institutionalization is not an inevitable process; nor is it unidirectional, monotonic or irreversible" (Weaver and Rockman, 1993).

"Institutionalism, as that term is used here, connotes a general approach to the study of political institutions, a set of theoretical ideas and hypotheses concerning the relations between institutional characteristics and political agency, performance and change. Institutionalism emphasizes the endogenous nature and social construction of political institutions. Institutions are not simply equilibrium contracts among self-seeking, calculating individual actors or arenas for contending social forces. They are collections of structures, rules and standard operating procedures that have a partly autonomous role in political life" (Marsh and Olsen, 2005:3). 
"Institutions are the rules of the game in a society or, more formally, are the humanly devised constraints that shape human interaction. Three important features of institutions are apparent in this definition: (1) that they are "humanly devised," which contrasts with other potential fundamental causes, like geographic factors, which are outside human control; (2) that they are "the rules of the game" setting "constraints" on human behavior; (3) that their major effect will be through incentives" (North, 1981, 1990:3 as in Acemoglu and Robinson 2008:2). This notion of operation with incorporation of rules, norms, and values are the fundamental principles for institutionalization process.

Sustainability concept is already institutionalized, with established discourses and is a major pillar for socioeconomic, and environment policy, planning and implementation. Sustainability is core prerequisite for the United Nations member countries. As noted in the United Nations (2015) in the Preamble of "Transforming our world: the 2030 Agenda for Sustainable Development",

"This Agenda is a plan of action for people, planet and prosperity. It also seeks to strengthen universal peace in larger freedom. We recognize that eradicating poverty in all its forms and dimensions, including extreme poverty, is the greatest global challenge and an indispensable requirement for sustainable development. All countries and all stakeholders, acting in collaborative partnership, will implement this plan. We are resolved to free people from the tyranny of poverty and want and to heal and secure our planet. We are determined to take the bold and transformative steps which are urgently needed to shift the world onto a sustainable and resilient path. As we embark on this collective journey, we pledge that no one will be left behind. The 17 Sustainable Development Goals (SDGs) and 169 targets which we are announcing today demonstrate the scale and ambition of this new universal Agenda. They seek to build on the Millennium Development Goals and complete what these did not achieve. They seek to realize the human rights of all and to achieve gender equality and the empowerment of all women and girls. They are integrated and indivisible and balance the three dimensions of sustainable development: the economic, social and environmental" (United Nations 2015:3).

It is noteworthy to note that, the preamble adequately explains the UN commitment for sustainability and to achieve the 2030 agendas of SDGs on institutionalized way. Further, on partnerships documents states "Partnership"- "We are determined to mobilize the means required to implement this Agenda through a revitalized Global Partnership for Sustainable Development, based on a spirit of strengthened global solidarity, focused in particular on the needs of the poorest and most vulnerable and with the participation of all countries, all stakeholders and all people. The interlinkages and integrated nature of the Sustainable Development Goals are of crucial importance in ensuring that the purpose of the new Agenda is realized. If we realize our ambitions across the full extent of the Agenda, the lives of all will be profoundly improved and our world will be transformed for the better" (UN, 2015:3). The declaration also openly offers the partnership with civil society organization, international organization, higher education institution and other stakeholders.

The declaration document states that, each country must prepare own plan to achieve 17 SDGs and 169 targets with their own institutional set up. There are 91 points in the declaration, SDGs are under pint 59 . Before documents declares the goals and target, it states "59. We recognize that there are different approaches, visions, models and tools available to each country, in accordance with its national circumstances and priorities, to achieve sustainable development; and we reaffirm that planet Earth and its ecosystems are our common home and that 'Mother Earth' is a common expression in a number of countries and regions" UN 2015:14).

These all efforts can be taken as the preparation of the institutional architecture of sustainability. These bold steps to attain the sustainability, highlights the scope and limitations of our planet's natural resources and ecological systems. Though it presented a great scope of future development with the wise use of available resources, it also presented a scenario how humankind's current and future uses of resources would diminish the carrying capacities of our ecosystems. The UN Declaration 2015 point 53 accepts this notion "53. The future of humanity and of our planet lies in our hands. It lies also in the hands of today's younger generation who will pass the torch to future generations. We have mapped the road to sustainable development; it will be for all of us to ensure that the journey is successful and its gains irreversible". The member governments have accepted this urgency of declaration and have created legal instruments, and institutions within their governments since the 1972 Stockholm Conference. Regarding the importance of institution on sustainability the Vice-Chairs of WSSD Anaedu and Engfeldt wrote:

Ensuring an effective institutional framework for sustainable development at all levels is key to the realization of the goals of sustainable development. To achieve these goals and to meet the emerging challenges, the sustainable 
development governance architecture needs to be strengthened at the international, regional, and national levels as these are inextricably linked and mutually interdependent. There is a clear need to enhance the responsiveness of the current institutional arrangements for the full implementation of Agenda 21, bearing in mind all relevant principles, including, the principle of common but differentiated responsibilities of States (2002:2).

'The above statement embraces the definition what Brundtland outlined in 1987 "development that meets the needs of the present without compromising the ability of future generations to meet their own needs" (p. 41). In line with the SD, the WSSD (2002) suggested to focus on six major areas in order to attain global sustainability. These include: Poverty eradication; Sustainable management and conservation of natural resources; Making globalization fit with the sustainable goals; Improving governance at all levels; and Providing funding for research to find alternative means through scientific and technological innovation to sustain the development (WSSD 2002; Schomberg 2002). Anaedu and Engfeldt (2002) proposed for the strong institutional development at the international, national, and regional levels in order to improve functioning in these areas. Prior to the WSSD meeting, the UN urged that it's Rio declaration signatory countries must submit a profile of their institutional strengths and weakness and should show their commitments to SD (Bhandari 2017).

An institutional perspective on organizations suggests that the processes and structure of an organization are a product of pressures exerted by the state, professions, and other members of an organization's field. Under this perspective organizational structures are not only a product of their objective functionality and market dependency as suggested by contingency, agency, and transaction cost theories, but rather are a combination of social meaning, symbolism and "action-generating properties" (Tolbert \& Zucker, 1999: 171).

Theoretically, institutions be social structures that have attained a high degree of resilience. Institutions are composed of cultural-cognitive, normative, and regulative elements that, together with associated activities and resources, provide stability and meaning to social life. Institutions are transmitted by various types of carriers, including symbolic systems, relational systems, routines, and artifacts (Scott 2004:48). Institutions operate at different levels of jurisdiction, from the world system to localized interpersonal relationships. Institutions connote stability but are subject to change processes, both incremental and discontinuous. Likewise, in relating to the environmental frame institutions provide the platform for the social practices, assign roles to the participants in these practices, and govern the interactions among the occupants of the various roles (Young, Schroeder and King 2002: xiv; Bhandari, 2018).

Institution covers large spectrum in the social context which include social networks, gender roles, legal system, politico-administrative system, and the state more generally - all of which interact with each other. Institutions are either state or non-state. State institutions cover many aspects, such as the public provision of basic education and health services, public order and safety, and infrastructure. The nature of governance will determine the availability and quality of these public services and, hence, the extent to which the poor have access to them. Non-state institutions are social institutions, values, and norms. A key social institution is social capital, which consists of informal norms or established relationships that enable people to pursue objectives and act in concert for common benefit. Social capital is particularly important for the poor. Ethnicity and gender roles, which still remain pronounced in the global context and lead to discrimination against minorities and females, are other institutions that underlie poverty and inequality (ADB, 2002:2). As indicated in the ADB report, institutional characteristics are largely explained in terms of economic institutions fueled by political power and political institutions. Economic institutions matter for economic growth because they shape the incentives of key economic actors in society. In particular, they influence investments in physical and human capital and technology and the organization of production. Economic institutions not only determine the aggregate economic growth potential of the economy, but also the distribution of resources in the society. Likewise, political power in society is also endogenous; which includes the political institutions as the form of government, system of governance like democracy versus dictatorship or autocracy, and the extent of constraints on politicians and political elites (ADB 2002; as in Acemoglu and Robinson, 2008:6-7).

\section{Table 7. Definitions}

\footnotetext{
Institution a cluster of rights, rules, and decision-making procedures that gives rise to a social practice, assigns roles to participants in the practice, and guides interactions among occupants of these roles

Multilevel governance that operates at two or more levels of social organization (e.g., local, regional, national levels)

New institutionalism a school of thought that explores the role of social institutions as sources of governance

Organization a group of people joined together to achieve a specific purpose. Typically, an organization has personnel, offices, equipment, a budget, and, often, legal personality (Young, Schroeder and King 2002, 2008)
} 
In relating to the environmental management institutions can be understood as the body of the environmental regimes' creator. Regimes constitute important components of governance systems at levels of social organization ranging from the local to the global. Institutions are distinct from organizations, which are material entities typically possessing personnel, offices, budgets, a legal personality, and so forth. Organizations play important roles in the administration and management of regimes dealing with a wide range of topics (e.g., the U.S. Environmental Protection Agency, the International Maritime Organization, and IUCN etc.) (Young, Schroeder and King 2002: xxi). In such case international institutions such as international conservation organizations like IUCN; multilateral agencies, such as the ADB and the World Bank, bilateral agencies like USAID, DFID have been playing the instrumental role for the institutionalization of environment conservation through explicit arrangements, such as treaties and conventions, that regulate behavior (Choo 2005:41) as well as by creating the policy for the governments but also to international organizations (IOs). IOs have been largely focusing for the involvement of concern stakeholders, beneficiaries and the community in the selection, design, implementation, and monitoring of environment and development projects. Similarly, IOs are also creating the partnerships with civil society groups, such as NGOs and CBOs, and helping them for further strengthened. IOs also has been playing important role for fostering the decentralized local government agencies instead of working solely with central government agencies including the local stakeholders of related fields (Acemoglu and Robinson, 2008: 56-57).

UN is the key player of institutionalize the sustainability. UN has been operating and organizing events and forums throughout the history-(Rio Earth Summit in 1992, Johannesburg Summit on Sustainable Development in 2002) and so on (Charnovitz, 1996, 1997; Gemmill and Bamidele-Izu, 2002:8) which ultimately boosting to institutionalize the sustainability discourses.

Theoretically, institutionalization of sustainability itself in trajectory. Institutionalization of sustainability is still young and new relevant perspectives, which can fully capture the underline essence still to be developed. There is a need of refining principles and practices to achieve the goals of sustainability. The boundaries of sustainability are beyond the limit. Technically, the world is getting smaller, however, the demands are widening and the gap of haves and not haves is increasing at the unprecedented rate. Therefore, the path ahead is very challenging. However, theoretically, institutionalization is an active process and many scholars have shown the intuitional changes and process of changes (Lawrence, and Lorsch, 1967; Galbraith, 1967; Williamson, 1975; Hannanand, and Freeman 1977; Zucker, 1977; Meyer, and Rowan 1977; North 1981; Keohane 1988; March and Olsen 1989, 2005; Powell, 1990; Oliver 1991; Opschoor 1991; Thelen and Steinmo 1992; Hannan, and Carroll, 1992; Aldrich and Fiol 1994; Strang, and Meyer 1994; Mearsheimer, 1995; Charnovitz 1996, 1997; Hall, and Taylo 1996; Theret, 2000; Valentin and Spangenberg 2000; Nielsen 2001; Young, et.el. 2002; Scott, 2004; Choo, 2005; Pfahl, 2005; Colyvas, and Powell 2006; IUCN 2006; Hák, Moldan, and Dahl, 2007; Duffield 2007; Acemoglu and Robinson 2008; Jepperson, and Platje 2008; Singh, et.el. 2009). Isomorphism process occurs within the institution. "Isomorphism is the constraining process that forces one unit in a population to resemble other units that face the same set of environmental conditions" ..... "We identify three mechanisms through which institutional isomorphic change occurs, each with its own antecedents: 1) coercive isomorphism that stems from political influence and the problem of legitimacy; 2) mimetic isomorphism resulting from standard responses to uncertainty; and 3) normative isomorphism, associated with professionalization. This typology is an analytic one: the types are not always empirically distinct. For example, external actors may induce an organization to conform to its peers by requiring it to perform a particular task and specifying the profession responsible for its performance. Or mimetic change may reflect environmentally constructed uncertainties.' Yet, while the three types intermingle in empirical setting, they tend to derive from different conditions and may lead to different" (DiMaggio and Powell, 1983:150).

In relation to institutional sustainability the concern is getting deeper, more innovative approaches are emerging. The 2015 declaration "Transforming our world: the 2030 Agenda for Sustainable Development" paves a positive pathway for the future; however, the outcome depends on how actual stakeholders act, plan and progress for the institutionalization of sustainability architecture. Higher educational institutions are key stakeholders for transferring or communicate the sustainability agendas through the curriculum. As such "sustainability does not simply require an 'add-on' to existing structures and curricula but implies a change of fundamental epistemology in our culture and hence also in our educational thinking and practice" (Sterling 2004:50). However, the it is necessary to examine on "how far institutions and higher education as a whole 
are able to respond sufficiently to the wider context of the crisis of unsustainability and the opportunities of sustainability. The common perception is often that little more than a change in teaching or curriculum is necessary - that is, an adaptive adjustment in learning provision. A full response, however, commensurate with the size of the challenge, implies a change of educational paradigm - because sustainability indicates a change of cultural paradigm which is both emergent and imperative' (Sterling 2004:50). The educational institution has to deal with the super complex scholarship of sustainability; whereas, sustainability touches all aspects of human life (Martins et. al., 2006) as well as Earth's carrying capacity.

\section{Conclusion}

The current world is interconnected economically, culturally, socially and politically due to technological development and globalization process. The diffusion of knowledge is also spreading at accelerating rate to the entire world. The demand of international laws was never as high as it is because of transnational problems HIV/AIDS, terrorism, as well as the globalizing, social, economic and bio-physical environmental problems. Institutions create 'set of rules, typically formalized in international agreements and embodied in organizations that stipulate the ways in which states should cooperate and compete with each other. They prescribe acceptable forms of state behavior and proscribe unacceptable kinds of behavior' (Mearscheimer 1995), therefore multidisciplinary approaches are needed to build strong institution (international institutions), which can help to minimize the global problems as listed on the United Nations 2015 declaration "Transforming our world: the 2030 Agenda for Sustainable Development". "14. We are meeting at a time of immense challenges to sustainable development. Billions of our citizens continue to live in poverty and are denied a life of dignity. There are rising inequalities within and among countries. There are enormous disparities of opportunity, wealth and power. Gender inequality remains a key challenge. Unemployment, particularly youth unemployment, is a major concern. Global health threats, more frequent and intense natural disasters, spiraling conflict, violent extremism, terrorism and related humanitarian crises and forced displacement of people threaten to reverse much of the development progress made in recent decades. Natural resource depletion and adverse impacts of environmental degradation, including desertification, drought, land degradation, freshwater scarcity and loss of biodiversity, add to and exacerbate the list of challenges which humanity faces. Climate change is one of the greatest challenges of our time and its adverse impacts undermine the ability of all countries to achieve sustainable development. Increases in global temperature, sea level rise, ocean acidification and other climate change impacts are seriously affecting coastal areas and low-lying coastal countries, including many least developed countries and small island developing States. The survival of many societies, and of the biological support systems of the planet, is at risk" (UN 2015:15). The declaration nicely articulate, how the people of the planet and planet is in trouble in present time and it tries to address these issues through SDGs. However, the challenges are deeper, and the world has not peaceful politically, socially, economically and the biophysical environment is deteriorating each and every day. There is still need of illuminating educational theory and practice which will enable human to think the world is our house and all living beings are our relatives and neighbors "Bashudhaiva Kutumbakkam" (Bhandari 2019). There is tradeoff between developing and developed world and there is no coherent frameworks or cooperation among the nations and even the various approaches in use to minimize the gap between North and South. So far there is no clear indication of how the aims of sustainability "to maintain the wellbeing of human and nature" will achieve.

And finally, I would like to conclude my responses with the quote of Margaret Mead and Marshall (1961). "Never doubt that a small group of thoughtful, committed people can change the world. Indeed, it is the only thing that ever has." (Mead). Yes, the change maker / charismatic leader, the thinker can be even a person who can influence for betterment of her / his community through small program and can be important step to empower society to archive desired goals. We have many such examples - Grameen Bank, Bangladesh, Greening program of Kenya, road belt or self-sufficiency - community forest program of Nepal. Here I would like to directly quote one of interesting conceptual program proposed by a prominent scholar of environmental domain from University of Louisiana Lafayette, Dr. Durga Poudel.

A decade ago, Professor Durga D. Poudel published a grassroots-based groundbreaking framework of AstaJa meaning eight Ja in Nepali letter, Jal (water), Jamin (land), Jungle (forest), Jadibuti (medicinal and aromatic plants), Janshakti (manpower), Janawar (animal), Jarajuri (crop plants) and Jalabayu (climate) as fundamental resources for economic development and socio-economic transformation in Nepal (Poudel, 2008). This publication was followed by a series of other publications on Asta-Ja Framework, which include, 
policy framework, strategic framework, and capacity building framework. Other subsequent publications on this framework include management of Asta-Ja system and the focus of Asta-Ja on national planning and development. Asta-Ja Framework suggests "Jalabayu” as the driving force for all other elements (Jal, Jamin, Jungle, Jadibuti, Janashakti, Janawar, and Jarajuri) and require full consideration of all eight elements while utilizing Asta-Ja resources for economic development. For example, for sustainable agricultural development (i.e. Jarajuri), all other seven Jas must be well utilized, conserved and developed. In other words, no sustainable agricultural production is possible without conservation of land, forest, water, appropriate Janashakti, and adequate consideration of Jalabayu. The eight principles of Asta-Ja Framework: community awareness, capacity-building, policy decision making, comprehensive assessment, interrelationships and linkages, sustainable technology and practices; institutions, trade and governance, and sustainable socioeconomic transformation and community development provide practical guidelines for design and successful implementation of policies and programs relating to Asta-Ja resources at the grassroots level.

Source: Paudel (2008) (copied and pasted with permission- 7-17-2019).

He states that if we keep the climate in central and manage properly, sustainably management of other seven aspects i.e. Water, land, forest, medicinal and aromatic plants, manpower, animal, crop plants would be easy. Here noticeable aspect is public participation in resources management. There are numerous examples of locally sustainably managed landscapes with the indigenous knowledge and techniques. However, such examples do not get highlights, because of inequal participation in decision making systems. The United Nations (2015) in the "Transforming our world: the 2030 Agenda for Sustainable Development" declaration3 states "We resolve, between now and 2030, to end poverty and hunger everywhere; to combat inequalities within and among countries; to build peaceful, just and inclusive societies; to protect human rights and promote gender equality and the empowerment of women and girls; and to ensure the lasting protection of the planet and its natural resources". (Declaration 3 page 3). However, in so far, instead of decrease inequality has been increased (Bertelsmann Stiftung and Sustainable Development Solutions Network 2018). UN declaration has been effective, however, there is no symbols of poverty reduction, opportunities are only accessible rich or who is in the power. Gender gap is not decreased, the rate of youth unemployment is on rise. Similarly, the impact of environmental degradation continues and frequent and intense natural disasters are common globally in recent decades. There are no symbols minimizing conflicts (local, national and international), and violence, extremism, terrorism, have been uncontrolled. Environmental degradation, which is one of the major threats of contemporary world, however, still there is no institutional architecture to address this challenge. Desertification, drought, land degradation, freshwater scarcity and loss of biodiversity, are still common circumstances. Global temperature is increasing, sea level is rising, and ocean acidification continues. Within four years of declaration implementation, there is no remarkable symptoms of improvements in listed problems. Even the G 20 Nations scenario of achieving SDGs is insignificant (Bertelsmann Stiftung and Sustainable Development Solutions Network 2018). As such UN Declaration "Transforming our world: the 2030 Agenda for Sustainable Development 2015" absolutely adds new hope discourse of sustainability; however, in so far, practicality seems questionable.

As principle, sustainability discourses capture the notion of social, economic and environmental boundaries, creativeness and innovation, and institutional architectures serve as tool to attain sustainability; however, the global challenges are mounted in every sphere of the globe. To achieve real sustainability strong commitment and instinctive motivation is needed. The program like Astha-J needs to get promoted and implemented. In so far, the invisible walls are everywhere and "my profit first" is the dominant approach of current development paradigms. To overcome the global challenges the concept of "BashudaivaKutumbakkam"- The entire world is our home and all living beings are our relatives" and Live and let other live- the harmony within, community, nation and global" is needed.

As I noted, earlier, my family, communities, and various societies (wherever I have been), including the nature and culture, traditions combinedly nurtured me, without any expectations. My intention, of life is to give or contribute to the society in fullest whatever I have. I would be more than happy, if readers find this information useful. I am open to engage in any kind of collaborative research, teaching, or any other tasks which can contribute to overcome or minimize the devastating impact of climate change and contribute to achieve the SDGs at any level. 


\section{Acknowledgements}

I would like to thank to Mr. Ram Chandra Gautam (my guru in every sphere of life), Prof. Douglas Capogrossi (my mentor, President of Akamai University, Hawaii), Prof. Bishnu Paudel (Guru of all of us), Mr. Kedar Neupane (UNHCR-Geneva), Dr. Ambika Adhikari (mentor for environment conservation), Prof. Gopi Uprety (Tribhuvan University, Nepal), Professor Durga D. Paudel (University of Louisiana Lafayete), Prof. Tulsi Dharel, (Centennial College, Toronto, Canada), Profs. Steven Brechin, Cecelia Green, Perter Castro, Hans Buechler, Marj DeVault (my mentor of research- Syracuse University), Prof. Keshav Bhattarai (Arizona State University), Dr. Puru Shrestha, Mr. Medini Adhikari (Equality Foundation), Mr. Guna Raj Luitel (INJAGlobal), Dr. Top Khatri, Dr. Sanjaya Mishra, Dr. Samuel H. Sage, Prof. Shvindina Hanna, Mr. Rajan Adhikari, Mr. Govinda Luitel, Mr. Pradeep Banskota, Gyanendra Bahadur Thapa, Mr. Durga Paudel (DNWC), Dr. Bijay Kattel, Dr. Jan Carey, Mr. William Turpie, Peter T. Se, Jahid Rahman, Mohamad Masum, and many others for their valuable suggestions, supports and encouragements throughout.

I would also like to remember my mentors (who are no more physically- including) Mr. Narayan Paudel (DNWC), Prof. Bhakta Lal Upadhaya, Prof. Ganesh Bhandari, Prof. Bill Katz, Mr. Edward Tedeschi, Mr. Krishna Bhusan Bal, Prof. Damodar Bharadwaj, Prof. Dilliram Timsina, Prof. Bal Krishna Pokhrel, Prof. Bhanu Bhakta Pokhrel, Prof. Narendra Chapagai, Prof. Herman Housing, and Laxmi Devi Bhandari, (grandma), Abhkesher Gautam and Jalapa Devi Gautam (m-Grandparent), Loknath Bhandari (my father), Dwarika Nath Devkota (Father in law), Maya Nath Bhandari, Dayananda Thakur, Dhaulai Mandal........ for their unconditional support to me on my journey towards environment management, sustainability, social and environmental justice.

I would like to thank to my wife and lifelong motivator, mentor Prajita Bhandari for her insightful comments, and inputs. I would also like thank to our son Prameya, daughter Manaslu, daughter in law Kelsey and granddaughter Neena and our family friend Abhimanyu for helping me to find relevant resources in the field of sustainability, inequality, social division, stratifications and gender issues. I would also like to thank to my mother Hema Devi, brothers Krishna, Hari, sisters Kali, Bhakti, Radha, Bindu, Sita and their families for encouraging me by providing peaceful environment. Thank you to all who directly or indirectly helping me on this complex trajectory of life.

\section{About Prof. Medani P. Bhandari}

Prof. Medani P. Bhandari completed his M.A. in Anthropology (Tribhuvan University, Nepal), M.Sc. Environmental System Monitoring and Analysis (ITC-The University of Twente, the Netherlands), M.A. Sustainable International Development (Brandeis University, Massachusetts, USA), M.A. and Ph.D. in Sociology (Syracuse University, NY, USA). He is dedicated to conservation of nature and natural resources and social empowerment through research and action project. His purpose of life is to give or contribute to the society fullest through whatever he has, earned, learned or experienced. He has worked with various organizations as consultant- United Nations Environment Program (UNEP)/Adelaide University, the United Nations Development Program (UNDP), the IUCN, the World Wildlife Fund (WWF), the World Resource Institute (WRI), Winrock International, the Japan Environment Education Forum, and the Pajaro Jai Foundation (PJF), along with others. During 2015-17, he served as a Professor of Natural Resources and Environment at the Arabian Gulf University, Bahrain. Prof. Bhandari has spent most of his career focusing on the Sociological Theories; Environmental Sustainability; Social Inclusion, Climate Change Mitigation and Adaptation; Environmental Health Hazard; Environmental Management; Social Innovation; Developing along the way expertise in Global and International Environmental Politics, Environmental Institutions and Natural Resources Governance; Climate Change Policy and Implementation, Environmental Justice, Sustainable Development; Theory of Natural Resources Governance; Impact Evaluation of Rural Livelihood; International Organizations; Public/ Social Policy; The Non-Profit Sector; Low Carbon Mechanism; Good Governance; Climate Adaptation; REDD Plus; Carbon Financing; Green Economy and Renewable Energy; Nature, Culture and Power. Prof. Bhandari's major teaching and research specialties include: Sociological Theories and Practices; Environmental Health; Social and Environmental research methods; Social and Environmental Innovation; Social and Environmental policies; Climate Change Mitigation and Adaptation; International Environmental Governance; Green Economy; Sustainability and assessment of the Economic, Social and Environmental impacts on society and nature. In brief, Prof. Bhandari has sound theoretical and practical knowledge in social science and environment science. His field experience spans across Asia, Africa, 
the North America, Western Europe, Australia, Japan and the Middle East. Professor Bhandari has published 4 books on environmental domain, 3 volumes of poems with Prajita Bhandari, hundreds of poems and essays on creative writing, and more than 60 scholarly papers in international scientific journals. Currently, he is serving as a Professor of Inter-Disciplinary Department - Natural Resource \& Environment / Sustainability Studies, at the Akamai University, USA and Professor of the Department of Finance and Entrepreneurship, Sumy State University (SSU) Ukraine; and International Program Coordinator, Atlantic State Legal Foundation, NY, USA (remotely).

\section{References}

1. Acemoglu, Daron and Robinson, James (2008). The International Bank for Reconstruction and Development / The World Bank, On behalf of the Commission on Growth and Development, The World Bank, Washington, DC http://www.growthcommission.org/storage/cgdev/documents/gc-wp-010 web.pdf.

2. ADB (2002). Poverty Reduction and the Role of Institutions in Developing Asia, ERD Working Paper Series No.10, Economics and Research Department, Asian Development Bank, Manila. https://www.adb.org/publications/poverty-reduction-and-role-institutions-developing-asia

3. Aldrich, Howard E. and C. Marlene Fiol (1994). Fools Rush in? The Institutional Context of Industry Creation, The Academy of Management Review, 19(4), 645-670. https://www.jstor.org/stable/258740

4. Anaedu, O. and Engfeldt, Lars-Goran (2002). Sustainable Development Governance. Paper prepared for consideration in the Second, Week of the Third Session of the Preparatory Committee for WSSD And Reserves to Sustainability Boundaries, River Research and Applications, River. Published online in Wiley Inter Science, (www.interscience.wiley.com). DOI: 10.1002/rra.1320.

5. Arima, A. (2009). A plea for more education for sustainable development. Sustain Sci, 4(1): 3-5. https://link.springer.com/article/10.1007/s11625-009-0071-7

6. Barbier, E. B., (1987). The concept of sustainable economic development. Environmental Conservation, 14(2), 101-110. DOI: https://doi.org/10.1017/S0376892900011449

7. Barker, Chris (2004). The SAGE Dictionary of Cultural Studies, SAGE Publications, London / Thousand Oaks I $\quad$ New Delhi https://zodml.org/sites/default/files/\%5BDr_Chris_Barker\%5D_The_SAGE_Dictionary_of_Cultural_0.pdf

8. Barnosky, A.D. (2012). Approaching a state shift in Earth’s biosphere. Nature 486, 52-58.

9. Basadur, M., Gelade, G., Basadur, T., (2014). Creative problem-solving process styles, cognitive work demands, and organizational adaptability. J. Appl. Behav. Sci., 50 (1), 80-115. http://www.businessanalytic.co.uk/ media/basadur-gelade-jabs-2014.pdf

10. Bertelsmann Stiftung and Sustainable Development Solutions Network (2018). SDG Index and Dashboards Report 2018-Global Responsibilities, Implementing the Goals, G20 and Large Countries Edition. www.picapublishing.com, http://www.sdgindex.org/assets/files/2018/00\%20SDGS\%202018\%20G20\%20EDITION\%20WEB\%20 V7\%20180718.pdf

11. Bhandari, Medani P. (2019). "BashudaivaKutumbakkam"- The entire world is our home and all living beings are our relatives. Why we need to worry about climate change, with reference to pollution problems in the major cities of India, Nepal, Bangladesh and Pakistan. Adv Agr Environ Sci., 2(1), 8-35. DOI: 10.30881/aaeoa.00019

12. Bhandari, Medani P. (2019). Live and let other live- the harmony with nature /living beings-in reference to sustainable development (SD)- is contemporary world's economic and social phenomena is favorable for the sustainability of the planet in reference to India, Nepal, Bangladesh, and Pakistan? Adv Agr Environ Sci, 2(1), 37-57. DOI: 10.30881/aaeoa.00020

13. Bhandari, Medani P. (2018). Green Web-II: Standards and Perspectives from the IUCN, Published, sold and distributed by: River Publishers, Denmark / the Netherlands ISBN: 978-87-70220-12-5 (Hardback) 978-87-70220-11-8 (eBook).

14. Bhandari, Medani P (2017). Climate change science: a historical outline. Adv Agr Environ Sci. 1(1) 1-8: DOI: $10.30881 /$ aaeoa.00002

15. Boucher, Lauren (2015). Sustainable Development Goals vs. Millennium Development Goals: What You Need to Know, Population Organization. https://populationeducation.org/sustainable-development-goalsvs-millennium-development-goals-what-you-need-know/

16. Callanan, Laura and Anders Ferguson (2015). A New Pilar of Sustainability, Philantopic-Creativity, Foundation Center, New York, https://pndblog.typepad.com/pndblog/2015/10/creativity-a-new-pillar-ofsustainability.html 
17. Carpenter S, Bennett E (2011). Reconsideration of the planetary boundary for phosphorus. Environmental Research Letters, 6: 014009. https://iopscience.iop.org/article/10.1088/1748-9326/6/1/014009/meta

18. Carson, Rachel (1962). Silent Spring. Boston: Houghton Mifflin Co. and in Rachel Carson, "Silent Spring," in Diane Ravitch, ed., The American Reader: Words that Moved a Nation (New York: HarperCollins, 1990). 323-325. http://www.uky.edu/Classes/NRC/381/carson_spring.pdf

19. Charnovitz, Steve (1996). Participation of Non-Governmental Organizations in the World Trade Organization, University of Pennsylvania, Journal of International Economic Law, 17, 331-357. https://www.law.upenn.edu/journals/jil/articles/volume17/issue1/Charnovitz17U.Pa.J.Int'IEcon.L.331(1996). pdf

20. Charnovitz, Steve (1997). Two Centuries of Participation: NGOs and International Governance, Michigan Journal of International Law, 281-282. https://repository.law.umich.edu/cgi/viewcontent.cgi?article=1466\&context=mjil

21. Choo, Jaewoo (2005). Is Institutionalization of the Six-Party Talks Possible? EASTASIA, 22(4), 39-58. DOI: $10.1007 / \mathrm{s} 12140-005-0003-9$

22. Clark, W. C., and R. E. Munn (1996-Eds.). Sustainable Development of the Biosphere. Cambridge: Cambridge University Press. http://pure.iiasa.ac.at/id/eprint/2751/

23. Colyvas, Jeannette A. and Walter W. Powell (2006). Roads to Institutionalization: The Remaking of Boundaries between Public and Private Science. Research in Organizational Behavior, 27, 315-363. https://doi.org/10.1016/S0191-3085(06)27008-44

24. Cornell, S. (2012). On the system properties of the planetary boundaries. Ecology and Society, 17:1. DOI: 10.5751/ES-04731-1701r02

25. Corral-Verdugo, V., Bonnes, M., Tapia-Fonllem, C., Fraijo-Sing, B., Frias-Armenta, M., \& Carrus, G. (2009). Correlates of Pro-Sustainability Orientation: The Affinity towards Diversity. Journal of Environmental Psychology, 29, 34-43. https://doi.org/10.1016/j.jenvp.2008.09.001

26. Costanza, Robert, Lisa Graumlich, Will Steffen (2007). Sustainability or Collapse: What Can We Learn from Integrating the History of Humans and the Rest of Nature? Ambio. http://wtf.tw/ref/costanza.pdf

27. Dacin, M. T. Goodstein, J. Scott, W. R. (2002). Institutional Theory and Institutional Change: Introduction to the Special Research Forum. Academy of Management Journal, 45(1), 45-57. https://researchportal.port.ac.uk/portal/files/1295255/GILMORE_2014_cright_JOCM_Institutional_the ory_and_change.pdf

28. Daly, H.E (2007). Ecological Economics and Sustainable Development, Selected Essays of Herman Daly, Advances in Ecological Economics, MPG Books Ltd, Bodmin, Cornwall http://library.uniteddiversity.coop/Measuring_Progress_and_Eco_Footprinting/Ecological_Economics_ and_Sustainable_Development-Selected_Essays_of_Herman_Daly.pdf

29. Daly, H., (1991). Sustainable development: From concept and theory towards operational principles, in tt. E. Daly, Steady-state Economics: 2nd Edition with New Essays, Washington, DC: Island Press. http://pombo.free.fr/daly1991.pdf

30. DESA (2013). World Economic and Social Survey 2013, Sustainable Development Challenges, Department of Economic and Social Affairs, The Department of Economic and Social Affairs of the United Nations Secretariat, NY. https://www.un.org/en/development/desa/publications/world-economicand-social-survey-2013-sustainable-development-challenges.html

31. Diamond, J. (2005). Collapse: How Complex Societies Choose to Fail or Survive. New York: Penguin http://cpor.org/ce/Diamond\%282005\%29Collapse-HowSocietiesChooseFailureSuccess.pdf.

32. DiMaggio, P. \& Powell, W. W. (1983). The iron cage revisited: Institutional isomorphism and collective rationality in organizational fields. American Sociological Review, 48, 147-160. https://www.uio.no/studier/emner/matnat/ifi/INF9200/v10/readings/papers/DeMaggio.pdf

33. DiMaggio, P. (2001). Making sense of the contemporary firm and prefiguring its future. In DiMaggio, P. (Ed.). The Twenty-First-Century Firm: Changing Economic Organization in International Perspective. Princeton: Princeton University Press. http://assets.press.princeton.edu/chapters/s7205.pdf

34. DiMaggio, P. J. \& Powell, W. W. (1991a). The iron cage revisited: Institutional isomorphism and collective rationality. Chicago: University of Chicago Press. http://woodypowell.com/wpcontent/uploads/2018/03/DiMaggioPowellThe-Iron-Cage-Revisited1983.pdf

35. Donald, Betsy (2010). The Creative Economy, Department of Geography Queen's University Monieson Centre Seminar Series, Canada http://business.queensu.ca/centres/monieson/events/Betsy Donald Creative Economy.pdf 
36. Dryzek, John S. (1997). The Politics of the Earth: Environmental Discourses, Oxford University Press. https://global.oup.com/academic/product/the-politics-of-the-earth-9780199696000?cc=ua\&lang=en\&

37. Duffield J. (2007). Reflection, evaluation and integration, What are the international Institutions, International Studies Review, 9, 1-22. https://www.jstor.org/stable/4621775

38. Duran, C.D., Gogan, L.M., Artene, A. \& Duran, V. (2015). The components of sustainable development - a possible approach. Procedia Economics and Finance, 26, 806-811. Retrieved November 20, 2015, from https://doi.org/10.1016/S2212-5671(15)00849-7.

39. Erb K-H et al. (2012). Pushing the Planetary Boundaries. Science, 1419-1420. https://www.eesc.europa.eu/resources/docs/sustainable-development-and-planetary-boundaries.pdf

40. Fleming, James R. (2004). Climate dynamics, science dynamics, and technological change, 1804-2004, Conference on International Commission On History Of Meteorology, Barocker Bibliothekssaal, Kloster Polling Weilheimer Straße, D-82398 Polling, Germany, http://www.meteohistory.org/2004polling_preprints/docs/polling_program.pdf http://www.meteohistory.org/2004polling_preprints/docs/abstracts/fleming_abstract.pdf (accessed on 04/03/2016)

41. Foley, J.A. et al. (2011). Solutions for a cultivated planet. Nature, 478, 337-342. https://www.nature.com/articles/nature10452

42. Folke, C. et al. (2011). Reconnecting to the biosphere. Ambio, 40, 719-738. https://www.ncbi.nlm.nih.gov/pmc/articles/PMC3357749/

43. Folke, C., Rockström, J. (2011). 3rd Nobel Laureate Symposium on Global Sustainability: transforming the world in an era of global change. Ambio, 40, 717-718. https://www.ncbi.nlm.nih.gov/pmc/articles/PMC3357755/

44. Galbraith, J.K. (1967). The New Industrial State, Houghton-Mifflin, Boston, MA. https://press.princeton.edu/books/paperback/9780691131412/the-new-industrial-state

45. Gilbert, Christine (2014). Sustainability's Inconvenient Discourse. Honors College, 177. https://digitalcommons.library.umaine.edu/cgi/viewcontent.cgi?article=1176\&context=honors

46. Gilbert, R., Stevenson, D., Girardet, H. and Stren, R. (1996). Making Cities Work: The Role of Local Authorities in the Urban Environment. Earthscan, London. DOI: https://doi.org/10.4324/9781315066431

47. Girard, Luigi Fusco (2010). Sustainability, creativity, resilience: toward new development strategies of port areas through evaluation processes, Int. J. Sustainable Development, 13(1/2), 161. https://ideas.repec.org/a/ids/ijsusd/v13y2010i1-2p161-184.html

48. Graedel, Thomas E. and Ester van der Voet (2010). Linkages of Sustainability, The MIT Press. https://mitpress.mit.edu/books/linkages-sustainability

49. Hák, T. and Moldan, B. and Dahl, A. (2007). Sustainability Indicators: A Scientific Assessment. SCOPE 67, https://www.researchgate.net/profile/Joachim_Spangenberg/publication/227650480_Institutional_sustai nability_indicators_An_analysis_of_the_institutions_in_Agenda_21_and_a_draft_set_of_indicators_for monitoring their effectivity/links/5b6d48bca6fdcc $87 \mathrm{df} 7095 \mathrm{c} 7 /$ Institutional-sustainability-indicatorsAn-analysis-of-the-institutions-in-Agenda-21-and-a-draft-set-of-indicators-for-monitoring-theireffectivity.pdf

50. Hall, Peter A. and Rosemary C.R. Taylor (1996). Political sciences and three new institutions, Political studies, XLIV, 936-957. https://doi.org/10.1111/j.1467-9248.1996.tb00343.X

51. Hannan, M T. and Carroll, G.R. (1992). Dynamics of Organizational Populations Density, Legitimation and Competition. Oxford University Press, New York. https://global.oup.com/academic/product/dynamics-of-organizational-populations9780195071917 ?cc=ua\&lang=en\&

52. Hannan, M.T. and J. Freeman (1989). Organizational Ecology. Cambridge, Massachusetts: Harvard University Press. https://www.hup.harvard.edu/catalog.php?isbn=9780674643499

53. Hannanand, Michael T. and John Freeman (1977). The Population Ecology of Organizations, AJS, 82(5), 929. https://www2.bc.edu/candace-jones/mb851/Apr9/HannanFreeman AJS 1977.pdf

54. Harwood, R.R. (1990). The history of sustainable agriculture. In C.A. Edwards et al. (Eds.). Sustainable Farming Systems (pp. 3-19). In Duran, C.D., Gogan, L.M., Artene, A. \& Duran, V. (2015). The components of sustainable development - a possible approach. Procedia Economics and Finance, 26, 806-811. Retrieved November 20, 2015, from https://doi.org/10.1016/S2212-5671(15)00849-7

55. Håvard Mokleiv Nygård (2017). Achieving the sustainable development agenda: The governance conflict nexus, International Area Studies Review, 20(1), 3-18. DOI: 10.1177/2233865916683609: 1-16. 
56. Haveman, Heather A. (2000). The Future of Organizational Sociology: Forging Ties among Paradigms, $\begin{array}{lll}\text { Contemporary } & \text { Sociology, } & \text { 476-486. }\end{array}$ https://www.researchgate.net/profile/Heather_Haveman/publication/254138626_The_Future_of_Organi zational Sociology Forging Ties among_Paradigms/links/0deec52f271b0d83ea000000/The-Future-ofOrganizational-Sociology-Forging-Ties-among-Paradigms.pdf?origin=publication_detail

57. Holvino, E., Ferdman, B. M. \& Merrill-Sands, D. (2004). Creating and sustaining diversity and inclusion in organizations: Strategies and approaches. In M. S. Stockdale \& F. J. Crosby (Eds.). The psychology and management of workplace diversity (pp. 245-276). Malden, Blackwell Publishing. https://psycnet.apa.org/record/2003-88187-000

58. Hornborg, A., J. R. McNeill and J. Martinez-Alier, (2007). Rethinking Environmental History: World System History and Global Environmental Change, AltaMira Press, Lanham, MD https://rowman.com/isbn/9780759110281/rethinking-environmental-history-world-system-history-andglobal-environmental-change

59. Ingram, J. (2011). A food systems approach to researching food security and its interactions with global environmental change. Food Security, 3, 417-431. https://www.semanticscholar.org/paper/A-foodsystems-approach-to-researching-food-and-its-Ingram/d669ba421038a2e11b701f51727304bac465de38

60. Ingrid Kajzer Mitchell and Jennifer Walinga (2017). The creative imperative: The role of creativity, creative problem solving and insight as key drivers for sustainability, Journal of Cleaner Production, 140, 1872-1884. https://tudelft.openresearch.net/image/2016/11/11/mitchel_walinga_jocp_2017.pdf

61. IUCN (1980). World Conservation Strategy: Living Resource Conservation for Sustainable Development. Retrieved November 7, 2015, from https://portals.iucn.org/library/efiles/documents/WCS-004.pdf.

62. IUCN (2006). The Future of Sustainability, Re-thinking Environment and Development in the Twentyfirst Century, IUCN, Gland (contributor W.M. Adams) http://cmsdata.iucn.org/downloads/iucn_future_of_sustanability.pdf

63. IUCN, UNDP \& WWF, (1991). Caring for the Earth. A Strategy for Sustainable Living. International Union for Conservation of Nature and Natural Resources, United Nations Environmental Program \& World Wildlife Fund Retrieved November 8, 2015, from https://portals.iucn.org/library/efiles/documents/CFE-003.pdf

64. James, Paul (Paul Warren). (2015). Urban sustainability in theory and practice: circles of sustainability / Paul James; with Liam Magee, Andy Scerri, Manfred Steger, Routledge (EarthScan). https://www.academia.edu/9294719/Urban_Sustainability_in_Theory_and_Practice_Circles_of_Sustain ability 2015

65. Jefferson, Thomas on Climate Change

$(15.10 .2008)$ http://xroads.virginia.edu/ HYPER/JEFFERSON/ch07.html; Found it in Dr Richard Keen's Global Warming Quiz, via Roger Pielke, Sr.'s Climate Science. http://omniclimate.wordpress.com/2008/10/15/thomas-jefferson-on-; http://americanconservativevalues.com/blog/2010/03/thomas-jefferson-fully-aware-of-climate-change/climate-change/

66. Jepperson, R. L. (1991). Institutions, institutional effects, and institutionalism. In P. J. DiMaggio \& W. W. Powell (Eds.). The new institutionalism in organizational analysis (pp. 143-162). Chicago: University of Chicago Press. https://www.press.uchicago.edu/ucp/books/book/chicago/N/bo3684488.html

67. Joost Platje (2008). "Institutional capital" as a factor of sustainable development - the importance of an institutional equilibrium, Technological and Economic Development of Economy, 14(2), 144-150. https://www.tandfonline.com/doi/pdf/10.3846/1392-8619.2008.14.144-150

68. Kates W. Robert, Thomas M. Parris \& Anthony A. Leiserowitz (2005). What is Sustainable Development? Goals, Indicators, Values, and Practice. Environment: Science and Policy for Sustainable Development, 47(3), 8-21, DOI: 10.1080/00139157.2005.10524444.

69. Keohane, Robert O. (1988). International Institutions: Two Approaches, International Studies Quarterly, 32(4), 379-396. http://www.rochelleterman.com/ir/sites/default/files/keohane1988.pdf

70. Klarin, Tomislav (2018). The Concept of Sustainable Development: From its Beginning to the Contemporary Issues, Zagreb International Review of Economics \& Business, 21(1), 67-94. DOI: https://doi.org/10.2478/zireb-2018-0005.

71. Laudel, Grit; Gläser, Jochen (1998). What are institutional boundaries and how can they be overcome? Germany's collaborative research centres as boundaryspanning networks, WZB Discussion Paper, No. P 98-401, Wissenschaftszentrum Berlin für Sozialforschung (WZB). https://www.econstor.eu/bitstream/10419/50922/1/25839188X.pdf 
72. Lawrence, P. R., Lorsch, J. W. (1967). Organization and environment. Boston: Graduate School of Business Administration, Harvard

University. https://www.hup.harvard.edu/catalog.php?isbn=9780875840642

73. Lélé, Sharachchandra M. (1991). Sustainable development: A critical review. World Development, 19(6), 607-621 https://edisciplinas.usp.br/pluginfile.php/209043/mod_resource/content/1/Texto_1_lele.pdf

74. Litfin, Karen (1994). Ozone Discourses: Science and Politics in Global Environmental Cooperation. https://www.amazon.co.uk/Ozone-Discourse-Environmental-Cooperation-Directions/dp/0231081375

75. Lorek, Sylvia and Doris Fuchs (2011). Strong sustainable consumption governance e precondition for a degrowth path? Journal of Cleaner Production, 30, 1-8. https://degrowth.org/wpcontent/uploads/2011/05/Lorek Sustainable-consumption.pdf

76. Mair, Simon, Aled Jones, Jonathan Ward, Ian Christie, Angela Druckman, and Fergus Lyon (2017). A Critical Review of the Role of Indicators in Implementing the Sustainable Development Goals in the Handbook of Sustainability Science in Leal, Walter (Edit.) https://www.researchgate.net/publication/313444041_A_Critical_Review_of_the_Role_of_Indicators_i n Implementing the Sustainable Development Goals

77. March, J.G. and J.P. Olsen (1984). The New Institutionalism: Organizational Factors in Political Life. $\begin{array}{lllll}\text { American Political } & \text { Science } & \text { Review, } & 78 & \text { (3), }\end{array}$ http://www.rochelleterman.com/ComparativeExam/sites/default/files/Bibliography\%20and\%20Summar ies/March\%20and\%20Olson\%201984.pdf

78. March, J.G. and J.P. Olsen (1986). Institutional perspectives on political institutions. Governance, 9 (3), 247-264. https://doi.org/10.1111/j.1468-0491.1996.tb00242.x

79. March, J.G. and J.P. Olsen (1989). Rediscovering Institutions. New York: Free Press.

80. March, J.G. and J.P. Olsen (1998). The institutional dynamics of international political orders. International Organization, 52, 943-69. Reprinted pp. 303-329 in P.J. Katzenstein, R.O. Keohane and S.D. Krasner eds. Exploration and Contestation in the Study of World Politics. Cambridge Ma: The MIT Press. http://courses.washington.edu/ppm504/MarchOlson_IO_98.pdf

81. March, James G. \& Johan P. Olsen (2005). Elaborating the "New Institutionalism" Working Paper No.11, March 2005, Center for European Studies, Oslo, Norway. http://www.arena.uio.no/publications/workingpapers2005/papers/wp05_11.pdf

82. Marin, C., Dorobanțu, R., Codreanu, D. \& Mihaela, R. (2012). The Fruit of Collaboration between Local Government and Private Partners in the Sustainable Development Community Case Study: County Valcea. Economy Transdisciplinarity Cognition, 2, 93-98. In Duran, C.D., Martins, Antonio A.; Teresa M. Mata and Carlos A. V. Costa (2006). Education for sustainability: challenges and trends, Clean Techn Environ Policy (2006) 8: 31-37. DOI: 10.1007/s10098-005-0026-3

83. Maser, C. (1997). Sustainable community development: principles and concepts, St. Lucie Press. https://books.google.cg/books/about/Sustainable_community_development.html?hl=fr\&id=4HHagTJL WfMC

84. Meadows, D.H. (1998). Indicators and Information Systems for Sustainable Development. A report to the Balaton Group 1998. The Sustainability Institute. https://www.iisd.org/pdf/s_ind_2.pdf

85. Meadows, D.H., Meadows, D.L., Randers, J. \& Behrens III, W.W. (1972). The Limits of Growth. A report for the Club of Rome's project on the predicament of mankind. Retrieved September 20, 2018, from http://collections.dartmouth.edu/published-derivatives/meadows/pdf/meadows_ltg-001.pdf.

86. Mearsheimer, John J. (1995). The False Promise of International Institutions, International Security, 19(3), 5-49. http://www.guillaumenicaise.com/wp-content/uploads/2013/10/mearsheimer_The-FalsePromise-of-International-Institutions.pdf

87. Meuleman, Louis (Ed.) (2013). Trans governance: Advancing sustainability governance, ISBN 978-3642-28009-2, Springer, Heidelberg, http://dx.doi.org/10.1007/978-3-642-28009-2.

88. Meyer, J.W. and Rowan, B. (1977). Institutionalized Organizations: Formal Structure as Myth and Ceremony. American Journal of Sociology, 83, 340-363. http://10x10learning.com/wpcontent/uploads/2016/05/Meyer-and-Rowan-LG639.pdf

89. Brundtland, G., ed. (1987). Our Common Future: The World Commission on Environment and Development, Oxford: University Press. https://sustainabledevelopment.un.org/content/documents/5987our-common-future.pdf

90. Mitchell, Ingrid Kajzer and Jennifer Walinga (2017). The creative imperative: The role of creativity, creative problem solving and insight as key drivers for sustainability, Journal of Cleaner Production 140, 1872-1884. https://tudelft.openresearch.net/image/2016/11/11/mitchel_walinga_jocp_2017.pdf 
91. Nielsen K. (2001). Institutionalist Approaches in the social Sciences: Typology, Dialogue and Future Challenges, Journal of Economic Issues, 32(2). https://www.jstor.org/stable/4227683?seq=1

92. Nielsen, K. (2001). Review of Institutionalist Approaches in the Social Sciences: Variety, Dialogue, and Future Prospects. Research Papers. Network Institutional Theory. No. 7. Roskilde: Roskilde University. DOI: $10.1080 / 00213624.2001 .11506385$

93. North, Douglass C. (1981). Structure and Change in Economic History. New York: W.W. Norton \& Co. https://doi.org/10.1177/003232928201100416

94. OECD. (1998). Sustainability Indicators beyond the Environment. OECD: Paris.

95. Oliver, C. (1991). Strategic Responses to Institutional Processes, Academy of Management Review, 16(191), 145-179. https://doi.org/10.5465/amr.1991.4279002

96. Opschoor, H., Reinders, L. (1991). Towards sustainable development indicators. In Search of Indicators of Sustainable Development, Kuik, O., Verbruggen, H. (eds). Kluwer: Dordrecht; 7-27. https://doi.org/10.1016/S0921-8009(96)00108-5

97. Ostrom, Elinor (1990). Governing the Commons: The Evolution of Institutions for Collective Action (Political Economy of Institutions and Decisions). Cambridge University Press. https://wtf.tw/ref/ostrom_1990.pdf

98. Paehlke, Robert C. (1989). Environmentalism and the Future of Progressive Politics, Yale University press.

Paehlke/dp/B000ORKDE2

99. Palmer, Len (2003). Discourses of sustainability: a foucauldian approach, The Regional Institute. http://www.regional.org.au/au/apen/2003/refereed/020palmerl.htm

100. PAP/RAC, (1999). Carrying capacity assessment for tourism development, Priority Actions Program, in framework of Regional Activity Centre Mediterranean Action Plan Coastal Area Management Program (CAMP) Fuka-Matrouh - Egypt, Split: Regional Activity Centre. https://papthecoastcentre.org/pdfs/CCA\%20for\%20Tourism\%20Development.pdf

101. Pearce, D. (1989). Tourism Development. London: Harlow.

102. Pesch, Udo (2014). Sustainable development and institutional boundaries, Journal of Integrative Environmental Sciences, 11(1), 39-54, DOI: 10.1080/1943815X.2014.889718.

103. Pfahl, Stefanie (2005). Institutional sustainability, Int. J. Sustainable Development, 8(1/2). https://d3pcsg2wjq9izr.cloudfront.net/files/6471/articles/6330/f326111104951287.pdf

104. Poudel, D.D. (2008). Management of Eight "Ja" for Economic Development of Nepal, Journal of Comparative International Management, 11(1), https://pdfs.semanticscholar.org/b545/05424a7994c449e26c7257ad76f0f8ec6e77.pdf

105. Powell, W. W. (1990). Neither market nor hierarchy: Network forms of organization. In Staw, B. M. \& Cummings, L. L. (Eds.). Research in Organizational Behavior, 12 (pp. 295-336). Greenwich, CT: JAI Press. http://www.uvm.edu/pdodds/files/papers/others/1990/powell1990a.pdf

106. Powell, W. W., Koput, K. \& Smith-Doerr, L. (1996). Interorganizational collaboration and the locus of innovation: Networks of learning in biotechnology. Administrative Science Quarterly, 41, 116-145. https://arizona.pure.elsevier.com/en/publications/interorganizational-collaboration-and-the-locus-ofinnovation-net

107. Powell, Walter W. and DiMaggio, Paul J. (1991). The new institutionalism in organizational analysis Chicago, IL: University of Chicago Press. https://www.press.uchicago.edu/ucp/books/book/chicago/N/bo3684488.html

108. Raworth, K. (2012). A safe and just space for humanity. Oxfam discussion paper. 26 pp. https://pdfs.semanticscholar.org/458c/d1325da288d260340826bd84af36bf450f99.pdf

109. Richter, Brian D. (2009). Short Communication Re-Thinking Environmental Flows: From Allocations. https://www.conservationgateway.org/Documents/Richter\%202009.pdf

110. Robin, Libby and Will Steffen (2007). History for the Anthropocene, History Compass, 5, http://www.blackwellcompass.com/subject/history/section home?section=hico-world

111. Rockström, J. et. al. (2009a). A safe operating space for humanity, Nature, 461, 472-475. https://www.nature.com/articles/461472a

112. Rockström, J. et. al. (2009b). Planetary Boundaries: Exploring the Safe Operating Space for Humanity, Ecology and Society, 14(2), 32. https://www.ecologyandsociety.org/vol14/iss2/art32/

113. Rockström, J., Karlberg, L. (2010). The Quadruple Squeeze: Defining the safe operating space for freshwater use to achieve a triply green revolution in the Anthropocene. Ambio, 39, 257-265. https://www.ncbi.nlm.nih.gov/pubmed/20701182 
114. Rockström, Johan and Jeffrey D. Sachs with Marcus C. Öhman and Guido Schmidt-Traub (2013). Sustainable Development and Planetary Boundaries, Background Research Paper, Submitted to the High Level Panel on the Post-2015 Development Agenda, Sustainable Development Network, https://www.researchgate.net/profile/Marcus Oehman/publication/257873780 Sustainable Developme nt_and_Planetary_Boundaries/links/004635260112637085000000/Sustainable-Development-andPlanetary-Boundaries.pdf.

115. Running, S.W. (2012). A measurable planetary boundary for the biosphere. Science, 337, 1458. http://leml.asu.edu/Wu-SIs2015F/LECTURES+READINGS/Topic_04-Global_SIIs/Readings-

Global_SDIs/Planetary\%20Boundaries/Running-2012-

A\%20measureable\%20planetary\%20boundary\%20for\%20the\%20biosphere.pdf

116. Sawyer, R. Keith (2002). A Discourse on Discourse: An Archeological History of an Intellectual Concept, Cultural Studies, 16(3), 433-456. https://doi.org/10.1080/09502380210128324

117. Schlör, Holger, Wolfgang Fischer, and Jürgen-Friedrich Hake (2015). The system boundaries of sustainability, Journal of Cleaner Production, $88, \quad 52-60$. https://econpapers.repec.org/article/eeeenergy/v 3a92 3ay 3a2015 3ai 3ap3 3ap 3a532-546.htm

118. Scoones, Ian (2016). The Politics of Sustainability and Development. Annu. Rev. Environ. Resour., 41, 293-319. https://www.annualreviews.org/doi/abs/10.1146/annurev-environ-110615-090039

119. Scott W.R. (2004). Reflections on A Half-Century of Organizational Sociology, Annual Review of Sociology, 30, 1-21. https://www.annualreviews.org/doi/abs/10.1146/annurev.soc.30.012703.110644

120. Scott, W. R. (2004). Institutional Theory: Contributing to a Theoretical Research Program, Great Minds in Management: The Process of Theory Development, Ken G. Smith and Michael A. Hitt, eds. Oxford UK: Oxford University Press. http://docshare01.docshare.tips/files/23333/233333690.pdf

121. Singh, Rajesh Kumar, H.R. Murty, S.K. Gupta, A.K. Dikshit (2009). An overview of sustainability $\begin{array}{llll}\text { assessment methodologies, ecological indicators } 9 & \text { (2009). 189-212 }\end{array}$ https://s3.amazonaws.com/academia.edu.documents/45427573/An_overview_of_sustainability_assessm ent_methodologies.pdf?AWSAccessKeyId=AKIAIWOWYYGZ2Y53UL3A\&Expires=1551372572\&Si

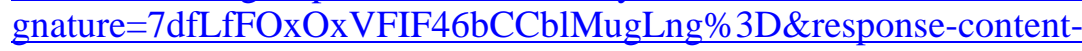

disposition=inline\%3B\%20filename\%3DAn_overview_of_sustainability_assessment.pdf.

122. Spangenberg J.H. (2001). Investing in sustainable development. International Journal of Sustainable Development, 4(2), 184-201. DOI: 10.1504/IJSD.2001.001554

123. Spangenberg, J.H. (2002). Institutional Sustainability Indicators: An Analysis of The Institutions In Agenda 21 And A Draft Set Of Indicators For Monitoring Their Effectivity, Sustainable Development, Sust. Dev., $10, \quad 103-115 . \quad$ http://tzyyling.ukn.edu.tw/seminar4/\%E5\%B0\%88\%E8\%A8\%8E\%E5\%A0\%B1\%E5\%91\%8A\%E5\%8F\%83\%E8 \%80\%83\%E8\%B3\%87\%E6\%96\%99/\%E7\%AC\%AC\%E4\%B8\%80\%E6\%AC\%A1/\%E8\%94\%A1\%E6 $\% 83 \% \mathrm{~A} 0 \% \mathrm{E} 6 \% 97 \% \mathrm{AC} /$ Towards $\% 20$ indicators $\% 20$ for $\% 20$ institutional $\% 20$ sustainability $\% 20$ lessons $\%$ 20from\%20an\%20analysis\%20of\%20Agenda\%2021.pdf.

124. Spangenberg, Joachim H.,Stefanie Pfahl, and Kerstin Deller (2002). Towards indicators for institutional sustainability: lessons from an analysis of Agenda 21, Ecological Indicators, 2, 61-77. https://www.researchgate.net/profile/Joachim_Spangenberg/publication/227650480_Institutional_sustai nability indicators An analysis of the institutions in Agenda 21 and a draft set of indicators for _monitoring their_effectivity/links/5b6d48bca6fdcc87df7095c7/Institutional-sustainability-indicators-

An-analysis-of-the-institutions-in-Agenda-21-and-a-draft-set-of-indicators-for-monitoring-theireffectivity.pdf

125. Steffen W et al. (2011). The Anthropocene: from global change to planetary boundaries. Ambio, 40, 739-761. https://www.ncbi.nlm.nih.gov/pmc/articles/PMC3357752/

126. Steffen, Will, Katherine Richardson, Johan Rockström, Sarah E. Cornell, Ingo Fetzer, Elena M. Bennett, Reinette Biggs, Stephen R. Carpenter, Wim de Vries, Cynthia A. de Wit, Carl Folke, Dieter Gerten, Jens Heinke, Georgina M. Mace, Linn M. Persson, Veerabhadran Ramanathan, Belinda Reyers, Sverker Sörlin (2015). Planetary boundaries: Guiding human development on a changing planet, Science 347, 1259855 (2015). DOI: 10.1126/science. 1259855.

127. Sterling, S. (2004). Higher Education, Sustainability, and the Role of Systemic Learning. In Corcoran P.B., Wals A.E.J. (eds) Higher Education and the Challenge of Sustainability. Springer, Dordrecht. https://www.springer.com/gp/book/9781402020261 
128. Sterling, S. (2010). Learning for resilience, or the resilient learner? Towards a necessary reconciliation in a paradigm of sustainable education. Environmental Education Research, 16, 511-528. DOI: 10.1080/13504622.2010.505427.

129. Stockholm Resilience Centre (2017). Transformation is feasible-How to achieve the Sustainable Development Goals within Planetary Boundaries- A report to the Club of Rome, for its 50 years anniversary $\quad 17 \quad$ October 2018, Stockholm Resilience Centre https://www.stockholmresilience.org/download/18.51d83659166367a9a16353/1539675518425/Report Achieving\%20the\%20Sustainable\%20Development\%20Goals_WEB.pdf

130. Strang, D. and J. W. Meyer (1994). Institutional Conditions for Diffusion. Institutional Environments and Organizations. W. R. Scott and J. W. Meyer. Thousand Oaks, SAGE Publications, 100-112. https://journals.sagepub.com/doi/abs/10.1177/000169939503800309

131. Sustainable Development Solutions Network-SDSN (2014). Health in The Framework Of Sustainable Development, Technical Report for the Post-2015 Development Agenda, Thematic Group on Health for All of the Sustainable Development Solutions Network, http://unsdsn.org/wpcontent/uploads/2014/02/Health-For-All-Report.pdf.

132. Lorek, Sylvia and Doris Fuchs (2011). Strong sustainable consumption governance e precondition for a degrowth path? Journal of Cleaner Production, 30, 1-8. https://degrowth.org/wpcontent/uploads/2012/11/Lorek- Fuchs-2013.pdf

133. Tahvilzadeh, Nazem, Stig Montin \& Mikael Cullberg (2017). Functions of sustainability: exploring what urban sustainability policy discourse "does" in the Gothenburg Metropolitan Area, Local Environment, 22(sup1), 66-85, DOI: 10.1080/13549839.2017.1320538

134. The Limits to Growth (1972). Abstract established by Eduard Pestel; A Report to the Club of Rome (1972). by Donella H. Meadows, Dennis 1. Meadows, Jorgen Randers, William W. Behrens III. http://www.donellameadows.org/wp-content/userfiles/Limits-to-Growth-digital-scan-version.pdf

135. Thelen, K., and S. Steinmo (1992). Historical Institutionalism in Comparative Politics. In Structuring Politics: Historical Institutionalism in Comparative Politics, edited by S. Steinmo, K. Thelen, and F. Longstreth. New York: Cambridge University Press, 1-32. http://www.rochelleterman.com/ComparativeExam/sites/default/files/Bibliography\%20and\%20Summ aries/Thelan\%201999.pdf

136. Tuan, Yi-Fu (1991). A View of Geography, Geographical Review, 81(1). pp. 99-107. http://www.jstor.org/stable/pdfplus/215179.pdf (accessed on 04/02/2016).

137. UN, United Nations (1972). Report of the United Nations Conference on the Human Environment. Stockholm. Retrieved September 20, 2015, from http://www.un-documents.net/aconf48-14r1.pdf.

138. UN, United Nations (1997). Earth Summit: Resolution adopted by the General Assembly at its nineteenth special session. Retrieved November 4, 2015, from http://www.un.org/esa/earthsummit/index.html.

139. UN, United Nations (2002). Report of the World Summit on Sustainable Development, Johannesburg; $\begin{array}{lllll}\text { Rio } & \text { Retrieved } & \text { November } & 4, & 2015,\end{array}$ http://www.unmillenniumproject.org/documents/131302 wssd report reissued.pdf.

140. UN, United Nations (2010). The Millennium Development Goals Report. Retrieved September 20, 2015, from http://www.un.org/millenniumgoals/pdf/MDG\%20Report\%202010\%20En\%20

141. UN, United Nations (2012). Resolution The future we want. Retrieved November 5, 2015, from http://daccess-dds-ny.un.org/doc/UNDOC/GEN/N11/476/10/PDF/N1147610.pdf? .

142. UN, United Nations (2015). Retrieved September 21, 2015, from http://www.un.org/en/index.html.

143. UN, United Nations (2015b). 70 years, 70 documents. Retrieved September 21, 2015, from http://research.un.org/en/UN70/about.

144. UN, United Nations (2015c). Resolution „Transforming our world: the 2030 Agenda for Sustainable $\begin{array}{lllll}\text { Development. } & \text { Retrieved } & \text { November } & \text { 2015, } & \text { from }\end{array}$ http://www.un.org/ga/search/view doc.asp?symbol=A/RES/70/1\&Lang=E.

145. UN, United Nations (2015d). The Millennium Development Goals Report 2015. Retrieved November 5, 2015, from http://www.un.org/millenniumgoals/2015_MDG_Report/pdf/MDG\%20

146. UNDESA-DSD - United Nations Department of Economic and Social Affairs Division for Sustainable Development, 2002. Plan of Implementation of the World Summit on Sustainable Development: The Johannesburg Conference. New York. UNESCO - United Nations Educational, Scientific and Cultural Organization, 2005. International Implementation Scheme. United Nations Decade 

of
Education
for
Sustainable
Development
(2005-2014).
Paris.

https://sustainabledevelopment.un.org/content/documents/Agenda21.pdf

147. UNDP (2010). Global Human Development Report 2010, Human Development Report Office, New York. http://hdr.undp.org/sites/default/files/reports/270/hdr 2010 en complete reprint.pdf

148. UN-DSD (United Nations Division for Sustainable Development) (2007). Indicators of Sustainable Development: Guidelines and Methodologies (3rd Edition) United Nations, New York http://www.un.org/esa/sustdev/natlinfo/indicators/guidelines.pdf

149. UNEP (2010). Background paper for XVII Meeting of the Forum of Ministers of Environment of Latin America and the Caribbean, Panamá City, Panamá, 26 -30 April 2010, UNEP/LAC-IG.XVII/4, UNEP Nairobi, Kenya http://www.unep.org/greeneconomy/AboutGEI/WhatisGEI/tabid/29784/Default.aspx.

150. UNEP (2012). Keeping Track of Our Changing Environment: United Nations Environmental Program From Rio to Rio+20 (1992-2012). Retrieved November 4, 2015, from http://www.unep.org/geo/pdfs/Keeping_Track.pdf.

151. UNEP, (2015). Green Economy. Retrieved November 5, 2015, United Nations Environmental Program from http://www.unep.org/greeneconomy/AboutGEI/WhatisGEI/tabid/29784/Default.aspx.

152. UNESCO (2013). UNESCO's Medium-The Contribution of Creativity to Sustainable Development $\begin{array}{llll}\text { Term } & \text { Strategy } & \text { for } & 2014-2021\end{array}$ http://www.unesco.org/new/fileadmin/MULTIMEDIA/HQ/CLT/images/CreativityFinalENG.pdf

153. UNFCCC, (2016). Report of the Conference of the Parties on its twenty-first session, held in Paris, United Nations Framework Convention on Climate Change, from 30 November to 13 December 2015. Retrieved February 15, 2016, from http://unfccc.int/resource/docs/2015/cop21/.

154. United Nations (1990). Institutions, Institutional Change, and Economic Performance. New York: Cambridge University Press. http://siteresources.worldbank.org/DEC/Resources/voigtfinal.PDF

155. United Nations (2002). Implementing Agenda 21 Report of the Secretary-General. Commission on Sustainable Development acting as the preparatory committee for the World Summit on Sustainable Development Second session 28 January-8 February 2002. https://iefworld.org/wssd_sg.htm

156. United Nations (2015). Transforming Our World: The 2030 Agenda For Sustainable Development A/RES/70/1, United Nations, New York https://sustainabledevelopment.un.org/content/documents/21252030\%20Agenda\%20for\%20Sustainable \%20Development\%20web.pdf

157. United Nations Department of Economic and Social Affairs (UNDESA) (1998). Measuring Changes in Consumption and Production Patterns. A Set of Indicators. UN: New York. https://sustainabledevelopment.un.org/index.php?page=view \&type $=400 \& n r=79 \& \mathrm{menu}=1515$

158. United Nations Department of Economic and Social Affairs (UNDESA) (2011). The Transition to a Green Economy: Benefits, Challenges and Risks from a Sustainable Development Perspective Report by a Panel of Experts* to Second Preparatory Committee Meeting for United Nations Conference on Sustainable Development Prepared under the direction of: Division for Sustainable Development, UNDESA United Nations Environment Program UN Conference on Trade and Development, New York http://www.uncsd2012.org/rio20/content/documents/Green\%20Economy_full\%20report\%20final\%20fo r\%20posting\%20clean.pdf.

159. United Nations Educational, Scientific and Cultural Organization (UNESCO) (2009). Bonn Declaration. UNESCO World Conference on Education for Sustainable Development, Bonn, Germany, 31 March to 2 April 2009. http://www.esd-world-conference2009.org/fileadmin/download/ESD2009_BonnDeclaration080409.pdf.

160. United Nations Environment Program and Development Alternatives- UNEP-DA (2008). South Asia Environment Outlook 2009: United Nations Environment Program (UNEP). South Asian Association for Regional Cooperation (SAARC) and Development Alternatives (DA) UNEP, SAARC and DA. http://www.saarc-sec.org/userfiles/SAEO\%202009.pdf.

161. United Nations General Assembly. (1987). Report of the world commission on environment and development: Our common future. Oslo, Norway: United Nations General Assembly, Development and International Co-operation: Environment. https://sustainabledevelopment.un.org/content/documents/5987our-common-future.pdf

162. Valentin, Anke and Joachim H. Spangenberg (2000). A guide to community sustainability indicators, Environmental Impact Assessment Review, 20, 381-392. DOI: 10.1016/S0195-9255(00)00049-4 
163. Van Dijk, T.A. (2011). Discourse studies: A multidisciplinary introduction. Sage. http://dx.doi.org/10.4135/9781446289068

164. van Dijk, Teun A. (1998). Ideology: A Multidisciplinary Approach, Sage Publications. http://www.discourses.org/OldBooks/Teun\%20A\%20van\%20Dijk\%20-\%20Ideology.pdf

165. van Dijk, Teun A. (2006). Ideology and Discourse Analysis. Journal of Political Ideologies, 11(2), 115140. https://doi.org/10.1080/13569310600687908

166. Vander-Merwe, I. \& Van-der-Merwe, J. (1999). Sustainable development at the local level: An introduction to local agenda 21. http://demarchesterritorialesdedeveloppementdurable.org/wpcontent/uploads/2013/07/our_community_our_future.pdf

167. Versteijlen, M.; Perez Salgado, F.; Janssen Groesbeek, M.; Counotte, A. (2017). Pros and Cons of Online Education as a Measure to Reduce Carbon Emissions in Higher Education in the Netherlands. Curr. Opin. Environ. Sustain, 28, 80-89. https://www.semanticscholar.org/paper/Pros-and-cons-of-online-education-as-ameasure-to-Versteijlen-Salgado/c9aa5aa2860414848a717720b6d5947366387790

168. Vos, Robert O. (2007). Perspective Defining sustainability: a conceptual orientation, Journal of Chemical Technology and Biotechnology, 1(82), 334-339. https://doi.org/10.1002/jctb.1675

169. Waheed, B.; Khan, F.I.; Veitch, B. (2011). Developing a Quantitative Tool for Sustainability Assessment of Heis. Int. J. Sustain. High. Educ. 12, 355-368. DOI: 10.1108/14676371111168278

170. Wallendorf, M.; Belk, R.W. (1989). Assessing Trustworthiness in Naturalistic Consumer Research. Interpret. Consum. Res., 69-84. http://www.aacei.acrwebsite.org/search/view-conferenceproceedings.aspx? $\mathrm{Id}=12177$

171. Wals, A., (2009). United Nations Decade of Education for Sustainable Development (DESD, 2005-2014): Review of Contexts and Structures for Education for Sustainable Development Learning for a sustainable world 2009. Paris. https://unesdoc.unesco.org/ark:/48223/pf0000148654

172. WB, The World Bank (2015). World Development Indicators. Retrieved September 2, 2015, from http://data.worldbank.org/data-catalog/world-development-indicators.

173. WCED (1987). Our Common Future World Commission on Environment and Development. New York: Oxford University Press. https://sustainabledevelopment.un.org/content/documents/5987our-commonfuture.pdf

174. Williamson, O. E. (1975). Markets and Hierarchies, Analysis and Antitrust Implications: A Study in the Economics of Internal Organization. New York: Free Press. https://lib.ugent.be/en/catalog/rug01:000031595

175. World Commission on Environment and Development (WCED) (1987). Our Comon Future, Oxford University Press, Oxford, p. 61. http://www.worldinbalance.net/pdf/1987-brundtland.pdf

176. World Conservation Strategy (1980). World Conservation Strategy: Living Resource Conservation for Sustainable Development. IUCN/WWF, 1196 Gland, Switzerland, and UNEP, Nairobi, Kenya. https://portals.iucn.org/library/sites/library/files/documents/WCS-004.pdf

177. Wu, SOS, Jianguo (Jingle) (2012). Sustainability Indicators Sustainability Measures: Local-Level SDIs494/598-http://leml.asu.edu/Wu-SIs2015F/LECTURES+READINGS/Topic_08-

Pyramid\%20Method/Lecture-The\%20Pyramid.pdf

178. Yao, L.J.; Bai, Y. (2008). The Sustainability of Economic and Cultural Impacts of International Students to Regional Australia. Humanomics, 250-262. https://www.emerald.com/insight/content/doi/10.1108/08288660810917132/full/html?fullSc=1

179. Yarime, M.; Tanaka, Y. (2012). The Issues and Methodologies in Sustainability Assessment Tools for Higher Education Institutions-A Review of Recent Trends and Future Challenges. J. Educ. Sustain. Dev. 6, 63-77. https://doi.org/10.1177/097340821100600113

180. Young, O. R. (2002). The institutional dimensions of environmental change: Fit, interplay, and scale. Cambridge, MA: MIT Press. https://mitpress.mit.edu/books/institutional-dimensions-environmental-change

181. Young, O. R. (2008). Building regimes for socioecological systems: Institutional diagnostics. In O.R. Young, L. A. King, \& H. Schroeder (Eds.). Institutions and environmental change: Principal findings, applications, and research frontiers (pp. 115-143). Cambridge, MA: MIT Press. https://mitpress.universitypressscholarship.com/view/10.7551/mitpress/9780262240574.001.0001/upso9780262240574-chapter-4

182. Young, Oran R.; Schroeder, Heike and King, Leslie A. Edits (2002). Institutions and Environmental Change, Principal Findings, The Institutional Dimensions of Environmental Change Applications, and Research Frontiers (Summary for Policy Makers) MIT Press, MA. https://mitpress.mit.edu/books/institutionsand-environmental-change 
183. Zucker, L. G. (1977). The Role of Institutionalization in Cultural Persistence, American Sociological Review, 42(5), 726-743. https://www2.bc.edu/candace-jones/mb851/Mar19/Zucker ASR 1977.pdf

184. Zucker, L.G (1991). The role of institutionalization in cultural persistence, in Powell, W.W, DiMaggio, P.J (Eds). The New Institutionalism in Organizational Analysis, University of Chicago Press, Chicago, IL, pp. 83-107. https://www.press.uchicago.edu/ucp/books/book/chicago/N/bo3684488.html 